Historic, archived document

Do not assume content reflects current scientific knowledge, policies, or practices. 



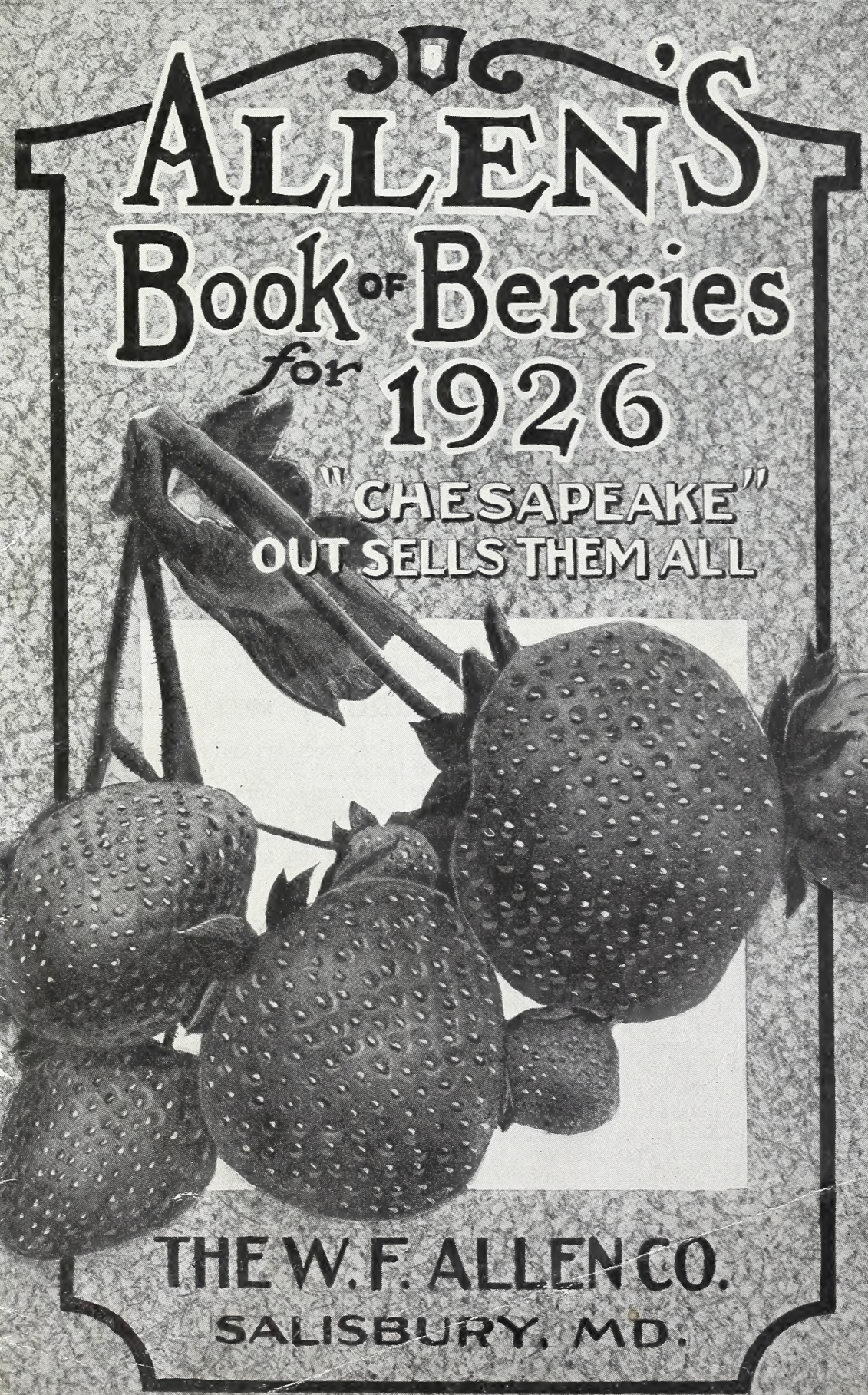




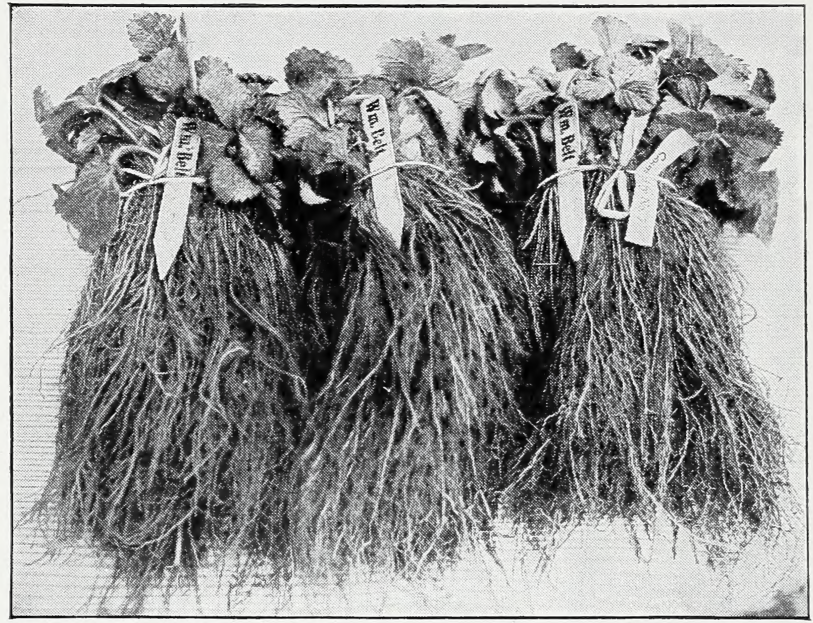

Good plants, correctly labeled, well packed

\section{Old Friends and New}

To all of you we want to extend our heartiest greetings and express the wish that 1926 may be a year of prosperity and happiness for you. Some of our customers have been receiving this Book of Berries annually for many years. Others will receive it this year for the first time. But we want you all to know that our policy is to treat all customers in such a way that they will come back and buy from us again. We believe our old custcmers realize this and the fact that they send us their orders year after year seems to prove it.

\section{The Plain Truth}

The plain truth is that we have the finest stock of the finest plants to offer you this year that we have had for many a year. The season here has been very short on rainfall, but what little we have had has been very evenly distributed, so that the plants have been "up and coming" all summer and fall. The grade of the plants we ship must be kept up to standard. Sometimes it is necessary to do this by discarding many of the smaller, inferior plants, sometimes it is because there are very few plants in the row so they all develop good crowns and roots but this year the grade is extra high and the plants we ship you will be strong, healthy, well-rooted plants, dug from strong, healthy, well-set beds, such as you want to give you a big, profitable crop of berries. Notice the pictures of the actual patches from which plants will be dug to fill our orders this year.

On the next three or four pages (if you will read them) you will find that we are trying to persuade you to grow strawberries, and, of course, use Allen's plants to start your beds from. That is true. But we have tried to stick to the plain truth in all the statements there. You will not find statements like these: "An independent fortune from two a cres of strawberries," or "\$1000.00 an acre sure if you'll do it our way." Such statements mean nothing. We do say that if you have some 
fairly good land available and a good market for strawberries, you can make good big profit growing them, more than from almost any other crop you can grow. And that is the plain truth.

On pages 12-15, we tell you that Allen's plants are good plants and why. Read those pages. You will find truthful statements about good plants.

Those who received our Berry Book last year and read our variety descriptions, will realize what we mean when we say our variety descriptions are truthful. We advised our customers not to buy at least 13 varieties of which we had a stock of plants-large stocks in some cases. Of course, we are discontinuing the poorest of these, but even after doing this, we are in several cases advising better varieties instead of the ones we have found to be less desirable. Mr. Frederick Unrath of Gloucester County, N. J., says, "Thank you for your prompt attention to my order for strawberry plants. The plants reached me Thursday, on schedule time, well packed, carefully labeled, clean and in excellent condition. Thank you, also, for the complimentaries. I marvel at the frankness which characterizes your catalog descriptions, and I think you have set an example which seedsmen and nurserymen generally may well emulate."

Naturally, we want your order for plants, not this year only, but next year, also, and as long as you need strawberry plants. We are sending you a catalog, not as large and showy as some, but dependable and truthful from start to finish. We believe our policy of fair dealing, moderate statements, good plants, and good service, will win for us the confidence and orders of our readers. Anyway, we are enclosing order sheet and return envelope.

\section{This Book Contains}

\begin{tabular}{|c|c|c|c|}
\hline How Much Profit? & Pages & & Pages \\
\hline eer........ & & $\begin{array}{l}\text { Midseason Varieties. } \\
\text { Late Varieties..... }\end{array}$ & $26-28$ \\
\hline ries in the Home Garden, & & Che & $24-2$ \\
\hline Methods. : & $8-10$ & Varieties & \\
\hline $\mathrm{s}, 12$ & & erries. & $30-3$ \\
\hline & & ons to Purchasers & \\
\hline & & Early? & \\
\hline Early Varieti & $20-22$ & Price List. & \\
\hline
\end{tabular}

\section{OUR TESTIMONIALS}

Yes, we are in business for profit, but not the least of our dividends is the many splendid letters received from our customer friends. We try hard to have every customer pleased by sending good plants, true-to-name, and packed to arrive in good condition, etc., and we are happy to receive the many letters of appreciation that come to our desk. Every one unsolicited and representing their spontaneous good will for having received fair and honest treatment. We enjoy reading these letters so much we want you to onjoy them with us, and hope everyone who receives this catalogut will read them, and we want to assure you that we will always strive to merit the many splendid compliments these letters contain.

$$
\text { Sincerely, }
$$

THE ALLENS. 


\section{How Much Profit?}

In spite of what you may read from the pen of enthusiastic plant growers, anxious for orders, as we are, you will not become suddenly rich by growing a few acres of strawberries. We have reports of $\$ 1000, \$ 1500$, and even $\$ 2000$ per acre profit from some of our customers, actual bonafide results. Some others may do this some of the time, but such cases are exceptional. Such large profits should not be expected nor should we as plant growers lead you to anticipate them.

We do believe there are good profits in growing strawberries for the man who will select the right varieties (see page 17), get good plants, and use proper methods. There is nearly always a good market for fancy berries. The amount of profit will depend on your growing costs and the selling price, (see page 6).

From one-fourth or one-half acre up to 5 or 6 acres, according to circumstances, are the plantings from which growers can expect big profits - possibly not $\$ 1000$ per acre, but still larger than from most any other crop. Given good land, the largest profits are usually made by those most favorably situated from a marketing standpoint.

Of course, large commercial growers who have plenty of land and help available and who can sell at an f. o. b. market or ship in carloads, can make money growing large acreages of strawberries. But most growers cannot do this and those who do do it do not get the profit per acre that the smaller grower does, who grows fancy fruit for a fancy market.

The Roadside Market is being used more and more in selling fancy berries. The requisites of a successful roadside market are: First, a location on a good road where there is lots of travel. It is not necessary to have an elaborate stand. As a business grows it might pay to put up more permanent places but a good start can be made by having a table or bench under a tree by the roadside. Select a place far enough back so motorists will have room to get at least a part of their machines off the road and not obstruct traffic. At the same time have your place visible as far as possible down the road. Second, good fruit, attractively displayed and prices in keeping with quality. Third, advertise by putting an attractive sign at the stand and perhaps by putting a small ad in a local paper.

We merely suggest the Roadside Stand as one more means of getting good prices for good fruit. It costs very little to try out this method of marketing your berries. This method is not adapted to plantings back off the main roads, although we have reports from some of our customers stating that their berries have such a high reputation that buyers leave the good roads and buy them at fine prices.

The old standby methods of selling berries at a profit are most suitable for many growers. A fancy retail trade directly with consumer or with retail stores, hotels, etc., is one of the best methods of marketing berries from a smali acreage. Others haul by truck or ship to wholesale dealers who are willing to pay good prices for good berries. Growers who select the right varieties and grow fancy fruit can practically always sell at a good profit.

\section{MORE THAN WE CLAIMED}

Monroe Co., W. Va., Mar. 19, 1925.

Please fine enclosed check for $\$ 15.50$ for 2500 strawberry plants. The Premier I got from you in 1923 were surely fine. They were more than you claim. I don't believe they can be over estimated. I am the only one around here that has tried them out. I had people from all over the neighborhood looking at them. I have another new patch this spring. Thanking you very much for past favor. W. E. FiELds. 


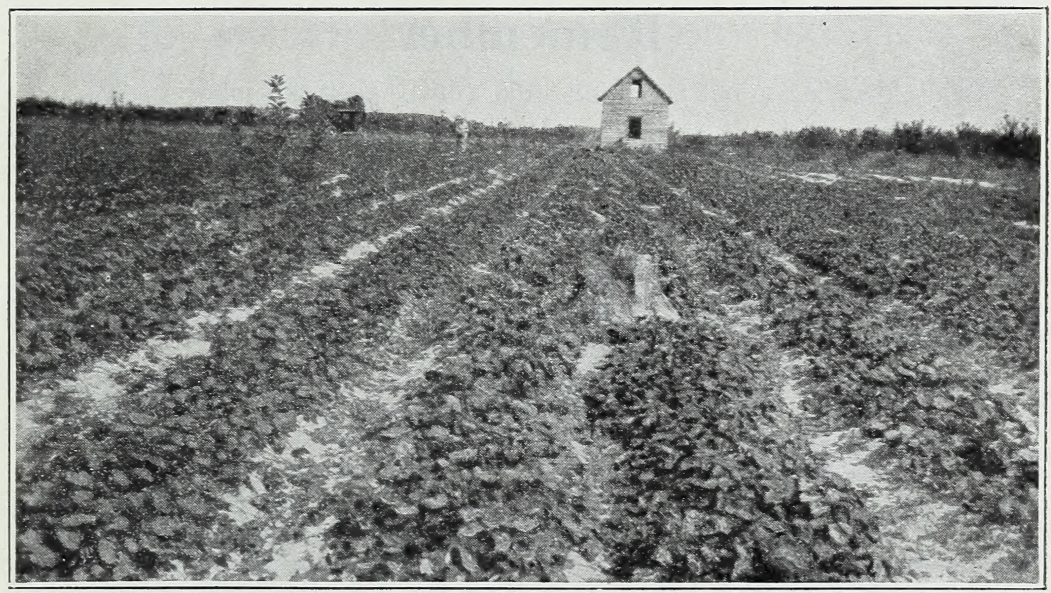

Fine beds of Big Joe for our customers this spring

\section{Everybody Likes Strawberries}

They like them because they are one of the most delicious and healthful of fruits, and because they come early, earlier than any other fruit. When the air begins to warm up and the sun lingers a little longer in the sky in springtime, most people long for something fresh from garden or field. They can get strawberries first, and get them they do.

This fact, coupled with the constantly increasing population, and the better methods of distribution for both fresh fruit and preserved products, makes a tremendous demand for strawberries.

The usual markets, hotels and restaurants, grocery and family trades, home canning and preserving always consume a tremendous quantity of strawberries, especially if the quality is good. Many people are learning that good fruit is a promoter of good health, and are demanding it one, two, of ten three times a day. Strawberries come when no other fresh fruit can be had.

Commercial canning and preserving is consuming an increasingly large quantity of fruit. And with sugar at a moderate price there seems to be no reason why this demand should not continue growing. We sell many thousands of quarts for this purpose each year. The beauty of this business is that small, overripe and sandy berries can be used for this trade, and thus keep the poorest fruit off the market. Fancy fruit never gluts a market.

Fruit Juices are increasing in demand at soda fountains, the strawberry flavor being a favorite with many. This is another outlet for inferior fruit, allowing only the best to go on regular markets.

Ice Cream factories are using strawberries more and more in their business. All of these needs must be supplied, and we believe at least a fair profit is sure for those who supply them. 


\section{Remember}

Before deciding to put off trying some strawberries, remember:

1. A comparatively large income can be had from a small acreage. Premier, Big Joe, Chesapeake and other good varieties (page 17) on rich land wellcared for, should yield at least 3000 or 4000 quarts per acre. Can you sell them at 20c per quart? Your growing costs including plants, labor and fertilizer should not be over $\$ 100$ to $\$ 200$ per acre. If you work them yourself and have stable manure available, the cash outlay can be cut in half. The above figures as to yield and growing costs are no more than a reasonable expectation. You can figure your chances for a good profit, depending largely of course on the probable market.

2. No previous experience is necessary. Follow cultural directions on pages 8-9, watch and talk with your neighbors if any of them grow strawberries successfully and use ordinary horse sense. If there is some point not covered in this Berry Book, write us. We will answer personally and help you if we can.

Mr. Wm. S. Hauze, of Carbon County, Pa., says, "You will find enclosed money order for \$12.00, for 2000 Premier Strawberry Plants. Will state I had 2000 Premier Plants of you in 1923 and had the finest berries in this section, and it was my first experience with berries at that. Hope I will get the same service again."

3. Any good garden soil or one that will make good yields of other crops will grow strawberries successfully.

4. Little money is needed to start. Besides the plants, a dibble or trowel for planting and a hoe and cultivator for working are all the equipment needed, once the ground is plowed.

5. The returns from Strawberry Growing are quick and come early in the season. No other fruit produces a full crop in 13 or 14 months after planting and no other fruit crop comes as early in the spring.

6. A Second Crop almost equal to the first can be had at very little additional expense.

7. Women Berry Growers are often among the most successful. No other crop is so adapted to being handled by women entirely as strawberries. Even where they are not running the berry business alone women take an active part in the work. It gives them a break in the routine of housework and affords an excellent opportunity to earn some extra money.

8. Berry growing can be made a family business. A farmer with a family can utilize the labor of his family at light, interesting work, and at a business which will pay well. The work is healthy, the pay is good, and the children can work in the open air and with their parents.

9. The boys and girls can be kept on the farm more easily by getting them interested. A small patch of strawberries of their own will afford an opportunity for pleasant work in the open where industry and diligence will be well rewarded.

10. Real Estate Values are increased by growing intensive crops like strawberries. So much can be done on a small piece of ground, that of ten rich high priced land in and near cities and larger towns can be profitably planted to strawberries.

11. As an intercrop between fruit trees, strawberries excel. The space can be utilized and made to pay with strawberries, while the trees are getting into bearing. 


\section{Strawberries in the Home Garden}

Everyonelikes them, and every family should have a strawberry garden, if there is a plot of land available, no matter how small. They will pay big dividends in health, pleasure and profits. The best berries are those grown in your own garden and picked fresh from the vines as you use them. They are delicious and the joy of having nice fresh berries for your own table every day fully repays for the effort required to plant and grow them. By using the everbearer Progressive or Champion the berry season can be extended through the summer and early fall until freezing weather.

Your grocery bill will be lessened by having your own strawberry garden. Not only do you save the cost of the berries you usually buy but you have more fine fruit than you ever use when you have it all to buy. You also save the cost of the other things that you don't want or need, now that you have plenty of strawberries.

There are many ways of preparing strawberries. Eating them "right off the vines" is popular with many folks. "Sugared down" for some time to let the juice come out is a favorite - perhaps the favorite method of eating strawberries. Strawberry shortcake might well be called the national dish. Fresh berries are used in soft drink preparations, in punch, in ice cream, and in many other ways.

Preserved strawberries are the most delicious of all the sweet foods we eat in winter. They are fine in conserves, marmalades, canned strawberries and strawberry jelly. There are many ways to "do up" berries and enjoy them throughout the year. Do up a lot of them, they will help out wonderfully "when winter comes."

Extra money. Some extra money for the housewife or children can readily be had from the home strawberry garden. 500 to 1,000 plants will produce sufficient berries for a large family and leave a good many to sell. There will be a market for them. If you have room in your garden try a good big plot. It will pay.

FINE PLANTS IN FINE SHAPE

Fulton Co., Ga., Feb. 20, 1925.

The strawberry plants received O. K. Fine shape and fine plants. Set out at once. Many thanks.

Mr. M. A. Bennett.

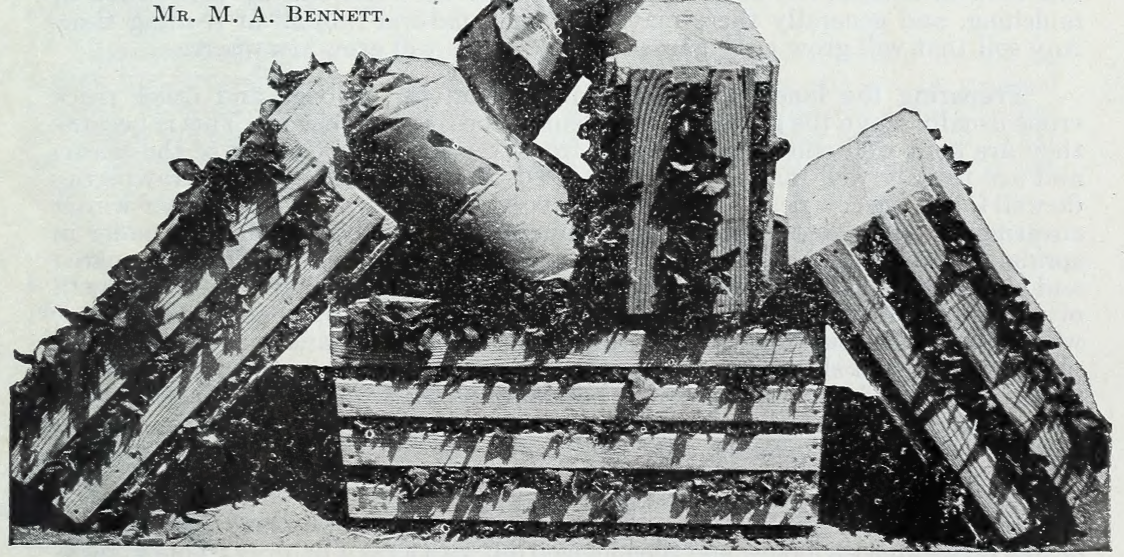

Good True-to-Name Plants, Packed, Ready to go 
run up two or three days before planting to allow the moisture to rise, and then rake off just before planting. Plowing, harrowing thoroughly, and marking off rows is the best for small fields and gardens. It is best for larger fields unless the grower is familiar with other methods that have worked well under his conditions.

\section{TIME TO PLANT}

Early Spring is the logical, natural, most successful and satisfactory time to set Strawberry plants. So don't neglect setting some plants this Spring, thinking you can make it up by early Fall planting. It can't be done.

How early? Just as soon as weather permits getting ground ready. In the South, February and March and early April. In the Middle States, March and April. In the Northern States, April.

Be sure to order early enough so that plants can be right at hand as soon as your ground is ready. Early setting pays big-the plants start quicker, grow better and make better beds than plants set late.

When a plant grower in the latitude of New York or Massachusetts can dig plants, berry growers in those sections should be setting their plants. This is a big advantage we can give growers in those latitudes. We can dig and ship plants earlier and have them right at hand for early planting.

Setting the Plants. Just before planting, the ground should be harrowed and made as level as possible. Then mark out the rows and you are ready to plant. There are a number of different methods of planting, but an ordinary garden trowel or a flat dibble are the best tools to use. Whatever tool is used try to have the roots of the plant spread out fan-shaped, and be sure to have the crown at the surface of the ground-not below nor above. Clipping the roots is not necessary nor helpful if you can get openings deep enough to have the roots straight when setting. It is better to have roots clipped a little rather than have them doubled up in the ground.

Manure and Fertilizer. The old saying "Tillage is Manure" holds true for strawberries. Thorough cultivation is essential.

Barnyard manure is the best thing to use for Strawberries. If used heavily on a crop just preceding strawberries, they get a maximum benefit for the residual manure. It is fine to use broadcast on the land and disced into the ground before the plants are set. Coarse manure is also fine to put on fruiting beds in fall to act as both mulch and fertilizer. Green crops turned in help where manure is not available.

Commercial fertilizer for starting young plants (either broadcast before plants are set or thoroughly mixed with the soil in the drill) should have $2-3 \%$ of available nitrogen and $5-10 \%$ or more available phosphoric acid. If put in furrow under plants it is likely to injure the plants unless moderate amounts are used and that thoroughly mixed with soil. As a top dressing for fruiting beds in spring a 7-6-5 or 4-8-4 fertilizer is most generally used in this section, although it has never been definitely shown that the crop is benefited by the potash.

We obtained the best results this season from commercial fertilizer under the plants before setting, that we have ever obtained. It was our own formula made up from a study of all the experimental evidence put out by all our experiment stations. We used $1500 \mathrm{lbs}$. of dissolved bone (3-9-0) and $500 \mathrm{lbs}$. of acid phosphate, $16 \%$ to make a ton of fertilizer, analyzing about 2.5-10.5-0. About $400 \mathrm{lbs}$. per acre of this was used in the drill and cultivated in thoroughly-going 
twice in each row with horse and cultivator to stir it in well. We planted young trees in one block and the tree rows were skipped. Our results were really remarkable. The fertilized rows started quicker and faster, grew better all season and now have lots more plants and better beds than the unfertilized rows. There are about 20 varieties in the field and the same results hold on all varieties.

But don't use too much of this. One grower in this county learned what we were using and tried it, also, but used $1000 \mathrm{lbs}$. per acre in the drill, and that not worked in as thoroughly as our $400 \mathrm{lbs}$. Result, he lilled about half of his plants, especially the side of his field which was highest and lightest. He probably could have used that much advantageously had he applied it broadcast and harrowed it in well.

Perfect and Imperfect Varieties. Perfect flowering varieties planted alone will mature a crop of perfect fruit. Imperfect flowering varieties should have perfect varieties planted with them, at least one row for every five or six. When two varieties are used in equal amounts, they are of ten alternated three or four rows of each. In our price-list, perfect flowering varieties are followed by "per"-imperfect varieties by "imp".

Mulching. A mulch is applied for one or all of three reasons: First, to protect the plants from freezing and thawing of the soil in winter; second, to keep the soil cool and moist during the season when fruit is being produced; third, to keep the berries from being spattered with dirt by rain during fruiting season.

The mulch should be applied in the fall. In the spring when plants begin to start this is raked to the center of the rows and there serves the purpose of retarding the growth of weeds and grass, keeping the ground loose and moist and the fruit clean. Use coarse manure, marsh grass, rye straw or similar material.

Green Manure Crops. In many sections where stable manure used to be plentiful and reasonably priced, it is now scarce and high priced. Green manure crops, properly handled, will take the place of stable manure very successfully. Sow soy beans or cow peas in late spring or early summer. We prefer broadcast sowing of these crops. Even though it takes more seed than row planting you do not need to cultivate and you get greater, finer and more evenly distributed crop of humus, including both tops and roots. Plow under in early fall and plant rye, wheat, or some other crops to hold the soil in winter. This fall sown crop should be plowed and disced very early in spring, however, to make room for early planting. Buckwheat in late summer makes lots of humus. Alfalfa, sweet clover, or in fact almost any crop that makes lots of humus, turned into the ground sometime ahead, leaves the soil in excellent condition for strawberry plants.

How Far Apart. We recommend setting plants in rows $31 / 2$ or $4 \mathrm{ft}$. apart. Set the plants from 18 to 24 inches apart in the row. Free growing varieties like Missionary, Dunlap, Paul Jones, etc., should be set 24 inches apart. Varieties like Chesapeake, Marshall and others that do not make plants freely should be set only 18 inches apart in the row.

\section{CANNOT PRAISE TOO HIGHLY}

Prince George Co., Md., March 30, 1925.

Please send the book of berries to the following parties: In connection with this cannot refrain from telling you that the plants I received from you two years ago produced the most wonderful berries it has ever been my lot to look at, and I have seen them grown in the North and in the extreme southern part of our country, and I have never seen such berries grown anywhere. The Florida berries cannot compare with them in the slightest degree, and while I only raise the berries for my own use, last season I had to sell about 400 quarts or just let them decay on the vines, and people were glad to get them at most any price even when there were lots of them on the market. I cannot praise them too highly. 


\section{A COMPLIMENT WE APPRECIATE VERY MUCH. THANK YOU!}

Bristol Co., Mass., Feb. 9, 1925.

Our old friend, Clother Pierce, told me once when I was down to his strawberry farm in Dighton to buy plants, that if I wanted some good plants, to seld to you as you had the best stock. And lie really meant what he said; a queer thing for a plant grower to do, wasn't it? I always meant to hand you that little tribute sometime. Lots of luck for 1925.

W. B. Pierce

\section{YOU ARE WELCOME, COME AGAIN}

San Luis Obispo Co., Cal., Apr. 23, 1925. I received your Strawberry plants in first-class condition. I thank you so very much.

L. B.AJER.

\section{SUCH SPLENDID ROOTS}

Fresno Co., Cal., Mar. 10, 1925.

My plants ordered in January received in due time, and every plant is growing. November is best time for the long trip. They get a bit dry beginning in January. such splendid roots brought them all out and all are doing well. I have had your plants in Nevada arrive as fresh looking as if from Fresno, Cal. Best wishes,

$$
\text { Sarah E. Evans. }
$$

\section{ARRIVED IN FINE CONDITION}

Sonoma Co., Cal., Feb. 19, 1925.

Just received order of strawberry plants. They arrived in fine condition. I am well pleased with them. Big Joe are the best, and the others, Premier, Chesapeake, Eaton and Wm. Belt are fine. Hoping to send you more customers and call again myself. Thanks for your promptness. Yours for strawberry plants.

Ernest A. Show Alter.

\section{HOPE YOU LIVE TO BE A HUNDRED, AND THEN SOME}

Hartford Co., Conn., Miar. 5, 1925.

I have a large number of your berry plants, and not much room for more. Moreover, I am eighty years old. But I must have some Everbearing and Chesapeake. The berries I had last year were the largest I ever saw.

George Henry Smith.

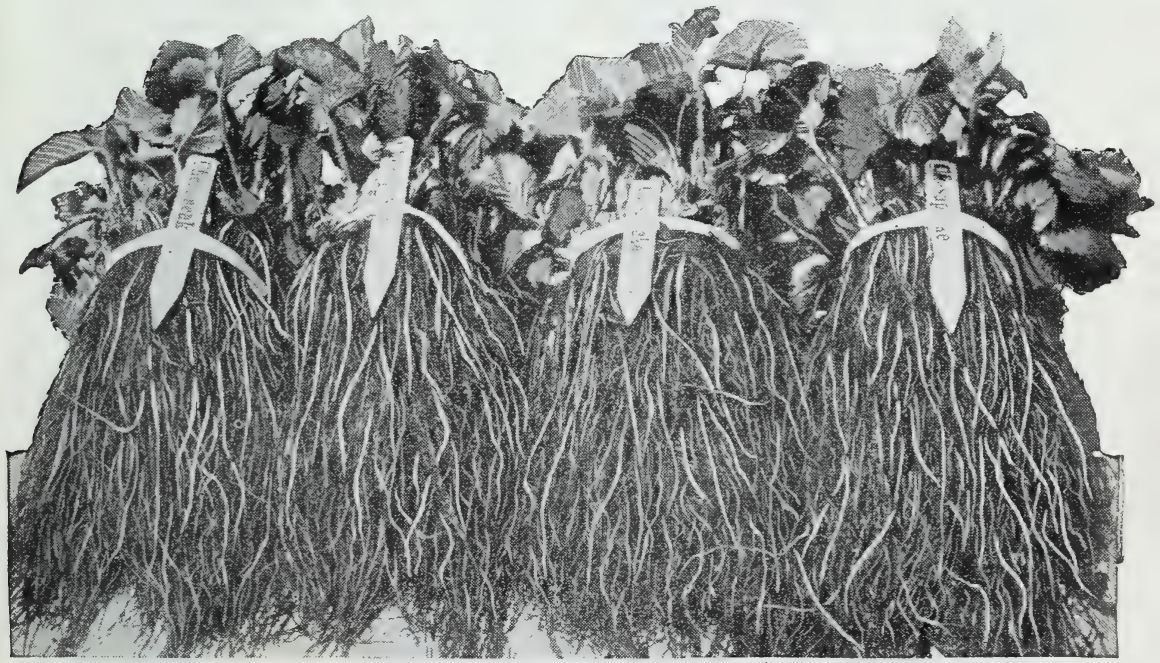

Fancy fruit from plants like these 


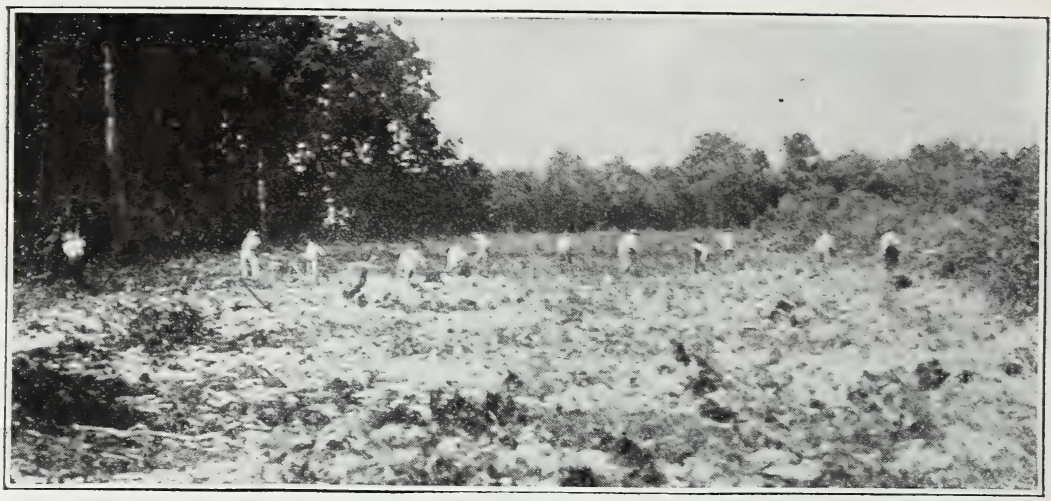

Clearing new land for Strawberries

\section{Good Plants Essential For Success}

Good plants mey not alwavs assure success, but poor plants are practically certain to mean failure. We believe our selected, true-to-name plants are good, and this is why:

1. Allen Plants are Grown Right. Good soil, plenty of organic matter, many of them grown in fresh new land. We encourage the young runners to take root just as early as possible to insure proper development and the fine root system for which our plants are famous. Clipping of the blossoms is another of the things we do to put more "pep" into our plants, by conserving the vitality that would have gone into the development of bloom and berry. Our young plants, except sometimes Everbearing, are never allowed to bear fruit.

2. Young Beds. All of our plants are dug from young beds. We never have dug and never expect to dig plants from old beds to fill our orders.

3. Root System. Our plants are grown in a light, sandy loam soil. In this type of soil any plant can develop its root-system to the fullest degree. And, having a light soil, we can dig plants without breaking off any of the great bunch of roots. With plants grown in heavier soils, the roots cannot penetrate the earth and make the root-system they do here; and, even if they could, it would not avail in giving fine plants, as plants are not removed from heavy clay soil without breaking off many of the fibrous roots, the kind necessary to start plant growth. We repeat, the root-system of our strawberry plants is never bettered, seldom equaled.

Mr. R. S. Eastin, of Henderson County, Ky., says, "Your plants are the finest rooted plants I have ever had, and I have a fine bed of them now in bloom. Last year I had the finest berries in the city."

Mr. C. E. Biever, of Dauphin County, Pa., wrote us, "I received my strawberry plants in fine condition. They had the longest roots on I ever saw. I believe they will stand the dry weather better than any others owing to their long roots. I planted them the same day I received them. Not a plant that did not grow. I expect to come down to see your place."

4. Allen's Plants are Healthy and Well Cleaned. Our plants are healthy and vigorous as grown in the field. Furthermore, our plants are well-cleaned; the dead and decaying runners and old leaves around the stems are trimmed off so that it would be very hard to transmit diseases even if they were present. 


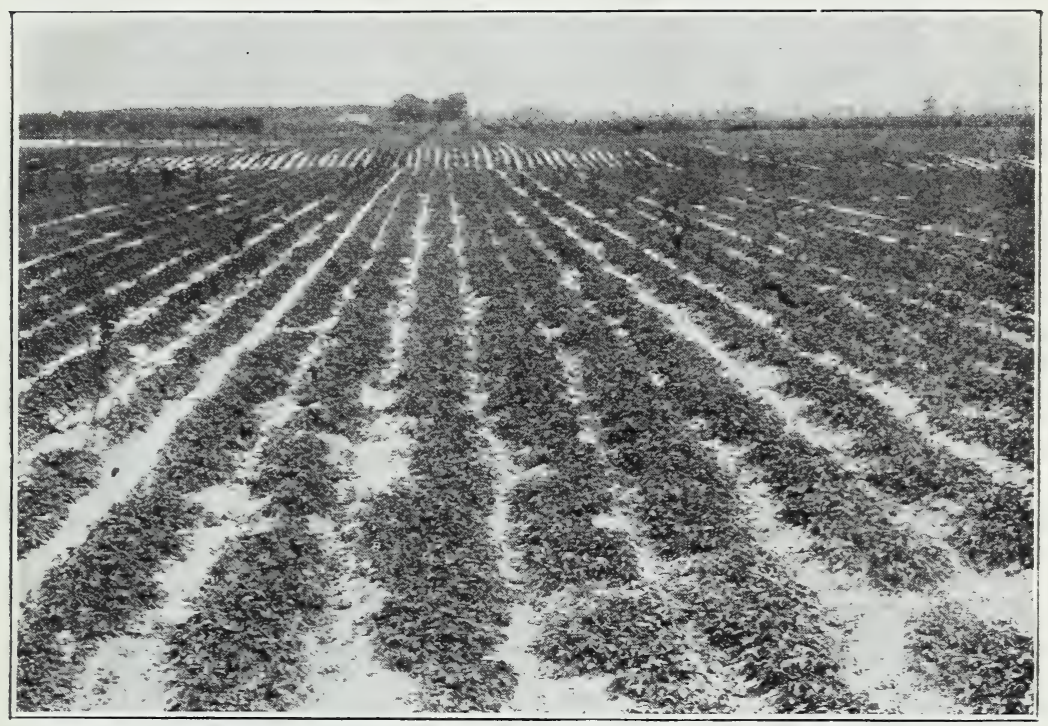

15 Acre Field of New Ground. Plants to be dug to fill our orders this spring. A year ago this field looked like the one in picture on opposite page

Plants that are sold at "bargain" prices of $\$ 2.50$ or $\$ 3.00$ per thousand are seldom well-cleaned. They must neglect this as well as many other things.

Mr. Charles T. Lowman, of Baltimore County, Md., says, "Your plants arrived in good shape, yesterday. They are, without exception, the prettiest and cleanest plants I have ever seen. Expect to have great pleasure in setting them out, and watching them grow."

5. Hardiness. Our plants are producing fine crops of berries in every state in the United States. We have numerous testimonials from Maine to California, from Florida to Michigan and from Vancouver to Nova Scotia in Canada. We supply many thousands of plants to Cuba and the Bermuda Islands. Wherever strawberries are grown successfully you will find many of the most successful growers using Allen's plants. They are hardy everywhere.

Iva Hesson, of Madison County, Indiana, says, "Since you recommend Wm. Belt so highly, I decided to set out a few in the small space I have. Your plants have always fruited heavier and withstood the late freezing weather we sometimes have better than plants from the North. Last spring my patch was white with blooms when a hard freeze came and blackened every heart. Your Premiers set on another fine crop and the plants were not injured while some others beside them almost died out."

6. True-to-Name. Don't waste a year's time and work growing your strawberry patch only to find at fruiting time you have small, inferior berries instead of the large luscious profit or pleasure-giving berries you expected. We believe our reputation for sending out true-to-name plants is second to none in this country. It will pay to get plants you know are true-to-name. We exercise the greatest care in keeping plants straight when planting. All our plants are labeled in the field when dug and the label is never taken from them until they are in the field or gardens of our customers. All plants are tied in bunches of 25 each and a printed wooden label is in each bunch. 
7. Grading and Packing. Our plants are dug fresh for shipment each day. Practically all of them are shipped out within 24 hours after they are dug. The plants are counted and bunched in our packing houses which have dirt floors. This prevents the wind and sun from drying out the roots, and the dirt floor also helps keep them fresh and moist. But the roots of all our plants are moistened before packing, which aids the plants in keeping fresh and "plump" in transportation, rather than dry and withered. The counters are instructed to throw out any broken, immature, poorly rooted plants, and close supervision is given to see that this is done. Twenty-five good plants are in each bunch. The plants are packed in light, strong crates. The tops of plants are packed outside to give air and prevent possible heating. The roots inside are well packed in light sphagnum moss to help keep the plants and roots fresh and moist. Neatly tied bundles and well straightened roots make planting easier, cheaper, and better.

Mr. D. M. Peck, of Meigs County, Ohio, says, "The plants you sent me surely are the finest plants that I ever saw. I am awfully well pleased with them. I send many thanks to The W. F. Allen Company. If I have good luck, I will have berries next spring as large as half gallon tins. Mr. Allen, my plants were sure in nice shape. The moss was nice and damp and the plants were just as fine as they were the day you put them up. Thank you for your kindness."

Mr. W. S. Lynn, of Forrest County, Miss., wrote us, "The strawberry plants that you shipped me on January 19th, arrived five days later, fresh as the Proverbial Daisy. I consider your plants the cheapest that I ever bought. Owing to their fine root system every plant grew, the Cooper being now in bloom. Being pruned, ready for setting, the express charges were less, the count was most liberal and I planted them in one-half the time required to plant untrimmed plants. For these reasons I can heartily recommend yours as a House selling Quality Plants Cheap."

8. Prompt Shipment. It adds something to the value of your plants to have them at hand at the proper time. We have the climate, the help and the personal supervision and interest in our business that gets things done on time. We can make prompt shipment of your order.

Mrs. W. F. Costin, of Northampton County, Va., says, "The Chesapeake Strawberry Plants came promptly and in good order. They were set out in two days, as they arrived Sunday, and I think I should tell you that I did not lose one, and they are simply flying. Never saw anything growing better."

Mr. J. W. Everal, of Franklin County, Ohio, wrote us, "I just wanted to write you folks concerning the last order I sent you and how it came out. Each party concerned acted without delay and everybody at this end of the line were very highly pleased with the splendid plants they got and the promptness in which their order was filled. It was surely a record breaker, considering the distance between the two principals. I passed my 80th birthday, March 3, 1925. Should I be living a year hence, I hope to still do some business with you."

Personal Interest and Supervision. As our old customers know, this business is run by Mr. W. F. Allen and three sons, Fulton, Lee and Albert. In "plant season" we are all on the job all day long, and usually well into the night. We personally supervise the digging, cleaning, counting and grading of your order. We actually do the packing ourselves, practically all the time. We see to it that you get good, true-to-name plants, properly put up, and packed to reach you in thrifty, growing condition. We believe this personal interest by men who have a lifetime experience in the business will be reflected in your results.

Allen's Selected True-to-Name Plants are your insurance against (1) undersized, poorly rooted plants; (2) mixed plants; (3) plants dried out by exposure to sun and wind in handling; (4) plants received in poor condition due to improper packing and other things which detract from the value of Strawberry Plants. 


\section{ONCE AN ALLEN CUSTOMER-ALWAYS AN ALLEN CUSTOMER}

Harford Co., Md., March 16, 1925.

Enclosed please find check in your favor to cover the enclosed order of one hundred strawberry plants. March, 1923, I ordered and received 200 plants of Prenier and 200 plants of Big Joe, from these plants I gathered 300 quarts of berries last year, of as fine berries as ever were seen in this section. I desire to add to my collection of fine berries a couple more varieties of fancier berries, and going through your catalog have picked out the Eaton and Chesapeake as the next best. If I am wrong, please substitute any that may be superior. I have ground in fine shape to plant at once, therefore please ship without delay.

\section{W. E. Carver}

\section{ALLEN'S PLANTS PLEASE EVERYWHERE}

Campbell Co., Ky., Aug. 25, 1925.

I want to take this opportunity of thanking you for the fine strawberry plants that you sen me on my order. The plants arrived here in the finest condition and certainly did fine, as long as I ever had strawberries, I never had any that equals the Premier that I purchased from you. I had a patch 20 feet by 30 feet and I gathered just about 200 quarts off these plants, and I had the first and last berries in this Campbell County.

\section{HeNRy IMmEgart.}

\section{WE ALWAYS RETURN EXCESS POSTAGE, IF ANY}

Baldwin Co., Ala., Mar. 12, 1925.

Your shipment of berries came duly, and in good condition. Also received letter with refund of $20 \mathrm{c}$ excess postage, for all of which please accept thanks.

Mrs. Elise M. Jones.

\section{ALLEN'S PLANTS IN ALASKA}

Alaska, Nov. 21, 1924

I received today the strawberry plants in good condition and am well pleased with them. I set them out and mulched them; happily cold weather did not set in yet, so I hope they will winter well You will hear from me next year.

E. Collin.

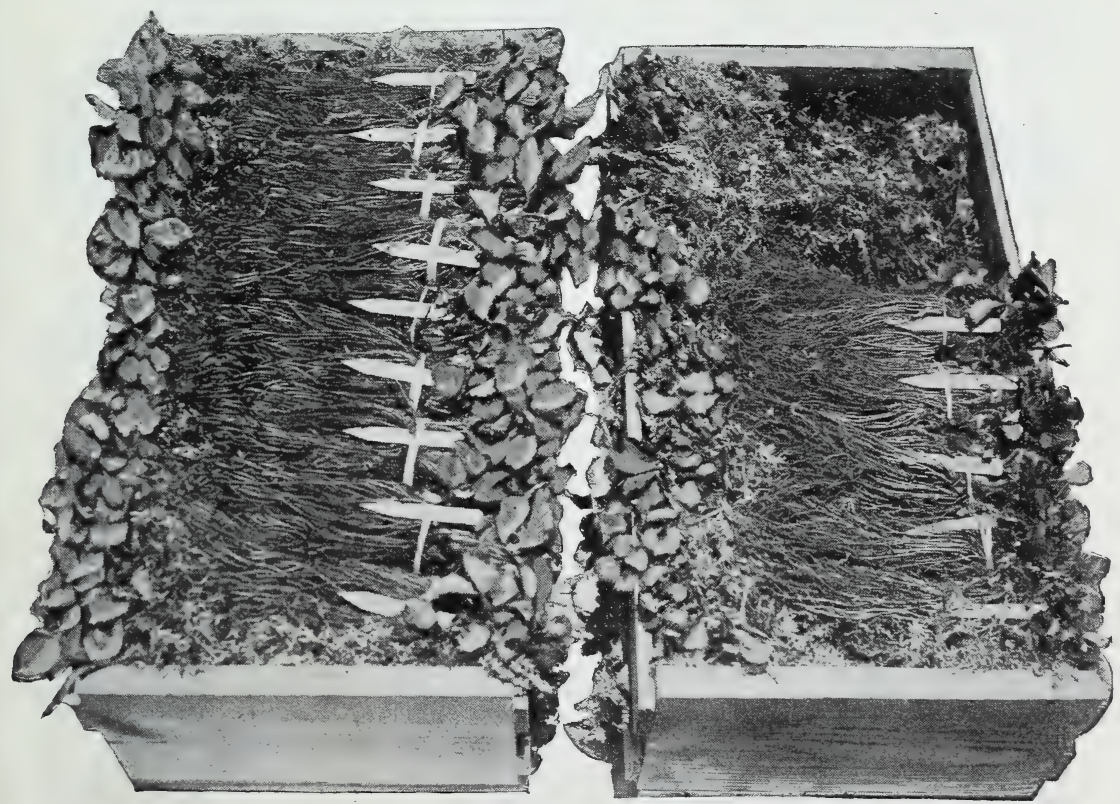

Good packing puts them to you in good condition 


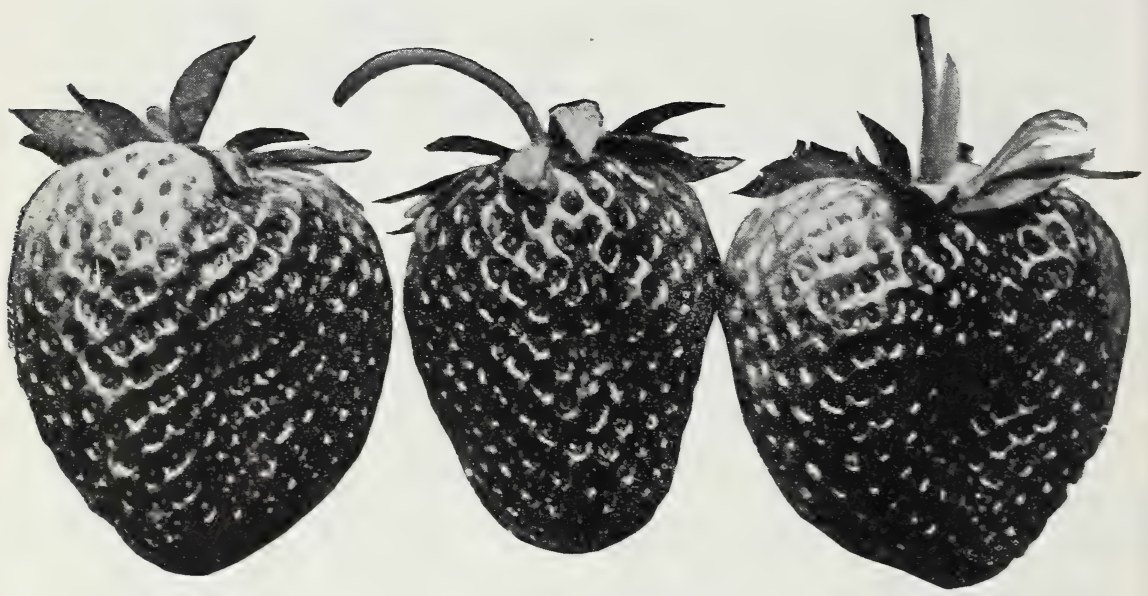

Everybody likes Premier

\$1000.00 PER ACRE

Montgomery Co., Ky., Feb. 9, 1925.

Enclosed find order and check for strawberry plants for a neighbor. I would like to say the Premier and Chesapeake plants I ordered of you for last year's crop made a yield at the rate of considerably more than $\$ 1000.00$ per acre. They were as fine as any of your pictures show.

\section{J. T. RICKETt.}

\section{PREMIER HIS CHOICE}

I Marion Co., Mo., Mar. 13, 1925. planted your Premier strawberries here a few years ago. We still are much in favor of the Premier and have decided after this to plant no other kind. We only want a few more this year, but after this year we will try our best to put in two or three acres at a time. From our experience we find the Premier has no equal in production, quality and appearance. Kindly give us a nice shipment of the enclosed order, and oblige AHREND MIEHRING.

\section{BETTER THAN WE RECOMMENDED}

Merrimack Co., N. H., Apr. 25, 1925.

Please send me 100 Progressive Everbearing strawberry plants. I ordered some Premier of you two years ago and found them better than you recommended them to be. They certainly are wonderful berries.

ROBERT E. PERKins.

\section{A SPLENDID SHOWING}

Lehigh Co., Pa., Feb, 21, 1925 .

We took your word and found Premier the best strawberry to plant. Berries ripened just about a week before otkers in our section. There were plenty of cheap shipped berries, but they did not count. Received $25 \mathrm{c}$ retail, $20 \mathrm{c}$ wholesale, and could have sold thousands of boxes more than we had.

Stephex J. Mertz.

\section{$\$ 175.00$ FROM \$6.00 WORTH OF ALLEN'S PLANTS}

Bradford Co., Pa., Dec. 12, 1925.

I was very well satisfied with my strawberry plants that I purchased from you during the spring of 1923 , and I wish to tell you a little about them at this time. I ordered 1000 Premier plants and they yielded nearing 1300 quarts. The bearing season continued through nearly four weeks. I am sending you a picture of a part of the largest day's picking. This picture shows only two of the six bushel that we picked during the one day. We received one hundred and seventy-five dollars for the berries, besides having all we cared for to eat on the table and in the strawberry patch, and gave some to the neighbors. The berries sold readily enough, that we were forced to turn down many ordeis. Expect to order more plants next spring.

Gordon A. Case. 


\section{What Varieties to Plant}

You will find the descriptions in this Berry Book accurate and dependable. We give the truth about all varieties as we have found them over a period of years and under different conditions.

There are too many varieties now. We believe on our local auction market the growers would realize money if only three or four, instead of nine or ten, varieties were grown.

New varieties are valuable only under certain conditions. The desire to have "something new" has led to the introduction of many varieties of little value. We believe no new variety should be introduced unless the introducer is convinced that it is better than any variety now on the market at least in some one important respect, as bigger, earlier, later, better quality, better shipper, etc.

For the man who wants great quantities of large, fancy berries of fine appearance and quality for home market or nearby shipment, we unhesitatingly recommend Premier for early, Big Joe for midseason, and Chesapeake, Wm. Belt or Big Late for late. Read what we say of these varieties and get your order in early. You can not do as well with any others.

Following close behind these five leaders and perhaps excelling some of them under certain conditions, are McAlpin, Senator Dunlap, Haverland, Glen Mary, Sample, Paul Jones, Gibson, Eaton and Gandy.

Of course, Klondyke and Missionary for early, and Aroma for late, are the great Southern shipping berries, destined to hold their own for many a day where berries must be shipped long distances. Aroma is a fine late variety, North or South.

\section{LEFT BEHIND}

Below we are giving a list of some of the varieties which we have grown and discarded during the last five years, because we have found others so much better.

\begin{tabular}{lll}
$\begin{array}{l}\text { Everbearing } \\
\text { Superb }\end{array}$ & \multicolumn{1}{c}{ Midseason } & Commonwealth \\
Americus & Ekey & Fendall \\
Peerless & Gold Mine & First Quality \\
Perfection & Magic Gem & Hustler \\
Gardeners 999 & Rewastico & Bate Jersey Giant \\
Early & Tennessee Prolific & Bun Wonder \\
Early Ozark & Warfield & Echo Special \\
Mitchell's Early & Delicious & Marvel \\
Judith & Shropshire & The Best \\
Early Jersey Giant & Late & Kellogg', Prize \\
Twilley & Amanda & Stevens' Late Champion \\
& Brandywine & Fremont Williams
\end{tabular}

You can use Champion for Everbearing, Premier for early, Big Joe for midseason, and Chesapeake, Big Late or Wm. Belt for late, and be much more sure of large crop of fancy berries than with any of the above list. 


\section{Premier (HOWARD 17)}

For several years we have been recommending Premier as the best early berry in existence. After another year's experience, we want only to emphasize what we have said in previous years. In addition to our own experience, we have enthusiastic reports from growers all over the Country about this variety. We are printing a few of them on page 16. We believe Premier comes nearer to being a perfect strawberry than any variety we have ever seen. It has no weak points. From our own experience and from the reports of many of our customers, we recommend Premier as being the best early berry to plant on any type of soil and in any section of the Country except Florida. We have grown Premier on rich land and on poor, on high land and on heavy, in wet seasons and in dry, in sea ons of many late frosts and in seasons where there were no late frosts and at all times Premier has outclassed other early berries. Each succeeding year demonstrates more fully that all we have said about Premier is true. For fear we will overlook some of the good points of this fine variety, we are going to list them.

1. You don't have to consider your soil. When grown on any soil and in any climate, Premier outclasses all other early berries.

2. The plants are enormously productive, ripening early and bearing through a long season. No variety yields more quarts per acre. This is especially important where the land is limited and a maximum quantity of fancy berries desired.

3 . The berries are beautiful in appearance, having a uniform shape and a glossy, rich red color extending clear through the berry.

4. The berries have a bright green cap which stays green to the end of the season even in dry weather. This is not oversize but just right to add the proper touch of beauty to the fruit. This results in greater beauty and a larger selling price.

5 . The berries are delicious in quality, equalled only by the very best ones like McAlpin, Big Late, Wm. Belt and Chesapeake.

6. Premier berries are firm enough to stand shipment to distant markets in good condition. We have heard buyers at local shipping stations condemn Premier as being a poor shipper, saying it did not ship like Klondyke. and in a few minutes later when a load of nice Klondyke and another of nice Premier drove through the auction market, these same buyers would pay from $25 \mathrm{c}$ to $\$ 1.00$ per crate more for the Premier. If kept picked up closely, Premier will come through a wet season with flying colors.

7. Premier is a fancy early berry which makes it easier for commercial growers to get pickers at the first of the season and keep them for late varieties, than if there were less desirable early berries, or none at all.

8. Premier is the nearest frost proof of any variety we have ever seen. For two successive years nearly all other varieties except Chesapeake were very severely damaged while Premier came through with a full crop. We believe Northern growers who have hesitated to plant early berries on account of late frosts can plant Premier and get by with a fine crop of fancy early fruit.

9. The berries are of large size and hold their size well throughout their long bearing season. As every strawberry grower knows, size is an important factor in getting a good price.

10. No variety has healthier foliage, and healthy foliage is essential in maturing a nice crop of fruit. The last two berry seasons here have given us extremes in weather. One was very dry and one very wet. In the dry year we had no rain during the entire picking season. That year most all of the varieties kept good foliage but were severely injured by the drought. And in a field that had nearly all the standard varieties and many of the newer ones like Eaton, Marvel, Delicious, Big Late, Big Wonder and others, Premier was not only the best early berry in the field, but discarding its early crop, it was better than any mid-season berry in the field, and discarding that it was almost as good as any late berry in the field except Chesapeake. The other year, which was one of the wettest strawberry seasons we have ever seen, a very large part of all the varieties rusted severely, and the size and quality of the crop produced was almost in direct proportion to the way the 


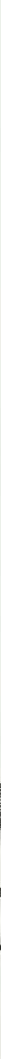

Premier-The finest early berry

foliage resisted the rust. Under those conditions there were three berries that stood out above the rest of the field. Premier and Chesapeake were vastly better than any other berries, and Big Joe considerably better than any except Premier and Chesapeake.

Summing it all up we would say that if you are going to grow strawberries, you can't afford to leave out Premier. If you can make some money with other varieties you can make lots of money with Premier. Price-list page 35.

\section{HOWARD 17 (PREMIER)}

This berry is identical with Premier. We recognized this fact several years ago and we said so in our catalog. It is now admitted by all growers of any standing who have tried them both out, although many held for a long time that there were some differences. We believe Howard 17 to be the best berry in the world, without any doubt. We sell many plants under the name Howard 17 and many under the name of Premier. The variety has received more advertising under the name of Premier, but there seems to be little doubt that Howard 17 is the original name, and many growers, especially in New England, prefer to use the name Howard 17 partly because they seem to feel that Mr. Howard has not received all the credit due him for originating this wonderful variety. For fuller description, see under Premier, pages 18-19. Price list, page 35. 


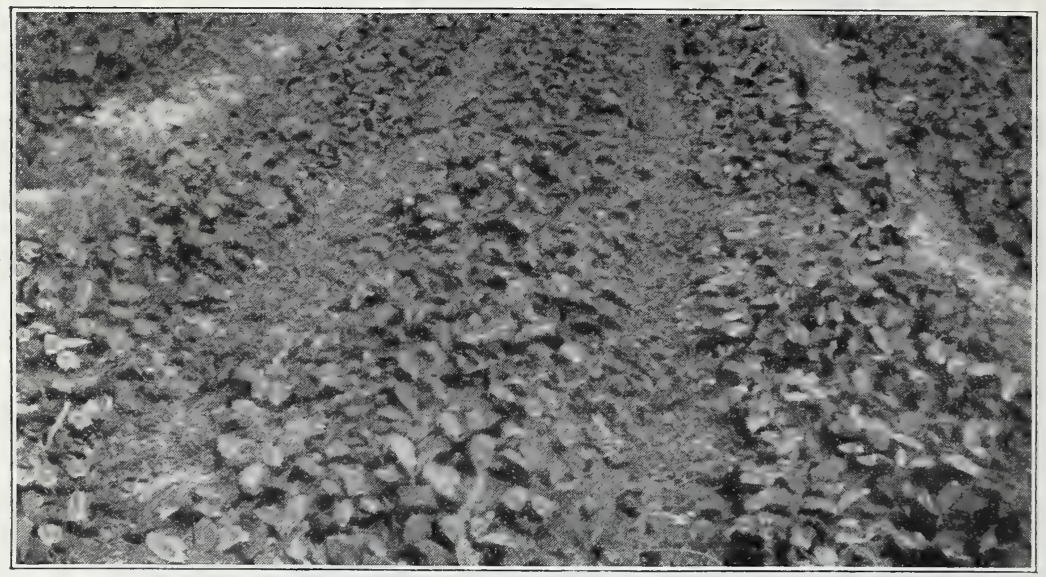

A close-up of our Dunlap plants

\section{Medium Early Varieties}

Senator Dunlap (Dr. Burrill). This variety does well on any type of soil and in any locality. Until Premier became so very popular, Senator Dunlap was prohably the most widely grown berry throughout the country north of the Mason and Dixon Line. It is said and is probably true, that Senator Dunlap will stand more abuse and still come through with a good crop of berries, than any other variety. The plants are rather small and on rich land should not be allowed to set too thick to secure best fruit. They have long, fibrous roots which makes them better than many others in a dry season. The berries are medium in size, bright, rich red clear through, and very good in quality. Dunlap ranks with Premier, Big Late and Paul Jones as the most productive varieties there are. The blossoms are perfect and produce a lot of pollen, making them one of the best to plant with imperfect varieties like Haverland and Paul Jones. For the inexperienced grower, Dunlap is safe. For the experienced grower, it is a fine old variety that has stood the test of time and not been found wanting. Price list, page 35 .

Cooper. This variety has been very highly recommended during the last two or three years, especially among Michigan plant men, as being a very wonderful new variety. They claim it to be the biggest berry grown, wonderfully productive, very high in quality, and so attractive in appearance that it commands the very highest prices on any market. We have fruited this variety for two years now. In the spring of 1924 the season was very wet and the foliage rusted badly, very much worse than Premier and Chesapeake, which did not rust at all in the same field, and considerably worse than Big Joe and Big Late. The plant growth is very strong and vigorous and at fruiting time the plants give promise of producing a very heavy crop of fruit. With the plants rusting badly as they did in the wet season, 1924, they did not mature a very large crop of berries although there were a few nice, big ones which were of fair quality, although not as good in quality as McAlpin, Chesapeake, Big Late and Wm. Belt. The spring of 1925 was considerably dryer and Cooper did better. In fact, except for Premier, it was about the best of the early and medium early varieties that we were fruiting. It produced a fairly good crop of big, handsome berries. The plants of Cooper have very long roots which would help it stand up in a dry year. Cooper seems to be a strong grow- 
ing, medium early variety, but, except for being a somewhat stronger grower, and a little larger in size, it is not the equal of Premier in any particular. The berries are too soft for long distance shipping. Our advice would be, then, to plant Premier for your main crop and plant Cooper in small quantities only, until it has proven its value for you. Price list, page 35.

Dr. Burrill (Senator Dunlap). We have tried for several years to find some difference between Dr. Burrill and Senator Dunlap. The introducer insists there is a difference but we have had them side by side several times and have never been able to see any difference. If there is a difference, it is so slight that there is absolutely no reason why a grower should plant one rather than the other. We believe any variation found will be as much due to a difference of soil or treatment as to the varieties themselves. For full description of Dr. Burrill, see Senator Dunlap, page 20. Price list, page 35.

Sussex. We have seen this variety fruiting in Sussex County, Delarare, just one time, the spring of 1924 . It is a strong growing, medium early variety, just a little later than Premier. At the place where we saw it, it was in the same field with Premier and the grower insists that it produced more berries, bigger berries and better shipping berries than the Premier. When we were there, it seemed that a larger part of the Premier had been picked than of this variety, but nevertheless it was a very promising sort. We recommend it as being well worth trying. Price list, page 35.

Klondyke. The leading market berry in many sections of the South. Missionary is grown more largely in Florida, and Aroma, a late berry, is grown more extensively in sections of Kentucky, Tennessee and Arkansas, but with those exceptions, Klondyke is probably the most widely grown berry of the Southern States. It

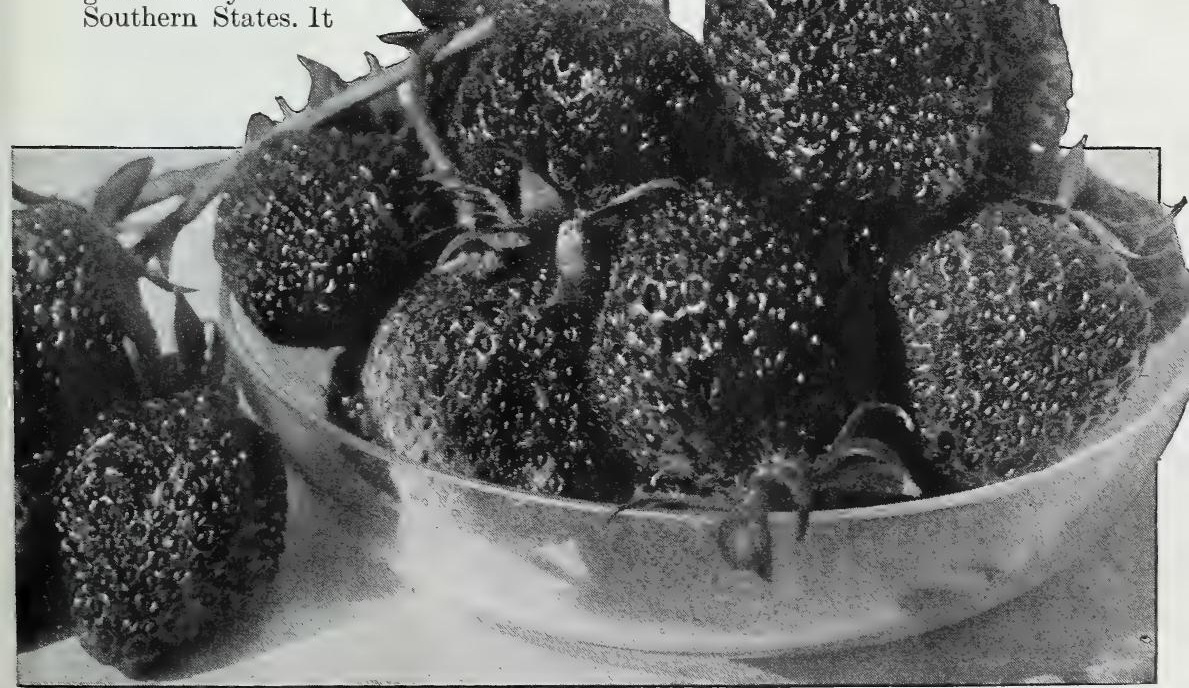

Senator Dunlap, Medium Size, vigorous and productive, easy to grow 


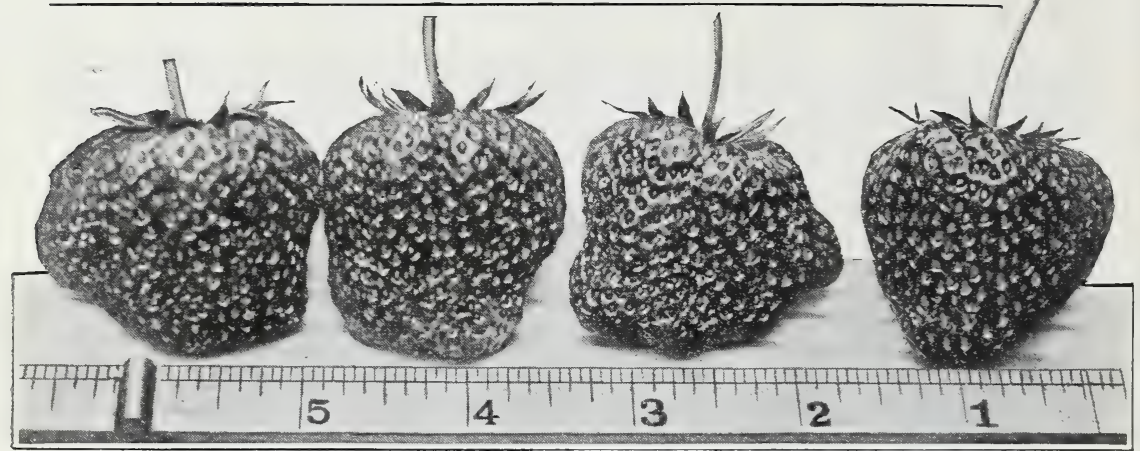

Eaton-A dandy Midseason Berry

makes a vigorous plant growth and is quite healthy. It bears a good crop, and the berries are medium to large in size, although it tends to run down some in size toward the end of the season unless the ground is quite fertile. The berries ripen evenly all over and are rather light in color, and most important of all, are firm enough to ship hundreds of miles and still get to market in perfect condition. Klondyke is not a home garden or local market berry, but it is one of the best for shipping long distances. Price list, page 35.

Missionary. Like Klondyke, this variety is very popular in the Southern States, in fact, in most all sections south of the Mason and Dixon Line where strawberries are grown in carload quantities. It is the most widely grown berry in Florida. Growers have often started picking this variety by Christmas, and usually get fancy prices for it on the Northern markets. This variety will do well on any kind of soil, but is especially adapted to light, sandy soils where a productive variety is needed and where berries must be shipped some distance. Missionary is more productive than Klondyke, but buyers on our local auction market will pay a little more for fancy Klondyke than for Missionary. Price list, page 35.

\section{Mid-Season Varieties BIG JOE (JOE JOHNSON) (JOE)}

(See illustration back cover)

Big Joe stands out as the best of the mid-season varieties and makes a wonderful running mate for Premier and Chesapeake. This variety does well on all types of soil, but, like many others, responds quickly to good care and fertility. Big Joe is one of the best money makers we have, especially when grown for local or nearby markets or where the shipping distance is not too great. The plant is a vigorous grower, very healthy and very productive. The berries are large in size and have a large, bright green cap which makes them very handsome and very attractive. They are also one of the best in quality. Market gardeners who retail their berries, those who sell at the farm or on roadside markets, or in fact, any one who can get a premium for large, handsome, high-quality fruit, should include Big Joe in their plantings. It is a strong pollenizer, making it valuable to plant with imperfect flowering, late varieties such as Haverland, Paul Jones, Big Late and Sample. A selection of Premier, Big Joe and Chesapeake for early, medium and late, would be a definite step in the right direction for getting pleasure and profit out of your strawberry patch. Price list on page 35 .

Eaton. We have grown Eaton now for several years, and find it one of the best of all the newer varieties. In fact, Eaton comes nearer to the standard set by Big Joe as the best mid-season variety we have than any other on our list. In some respects, it is slightly superior to Big Joe being perhaps a little more productive 
and a little firmer. However, the berries are not as large in size, not as handsome in appearance and not quite as good in quality. It is a variety well worth trying, and in case you have tried Big Joe and found that it doesn't quite suit your soil or climate, we would try Eaton as the most likely mid-season berry to take its place. We have a nice stock of plants of this variety, and we feel that it will pay strawberry growers to, at least, give it a trial. Price list, page 35.

Glen Mary. In the Middle and Northern States where Glen Mary is at its best, probably no variety of strawberries will produce more quarts per acre. The berries are large, firm enough to ship, of handsome appearance and good quality. Glen Mary is a strong grower and produces an abundance of foliage. The blossoms are about half perfect, but carry enough pollen for their own fruit. However, we believe the size and quality of the berries can be increased by planting a few rows of some strong pollenizer, such as Big Joe. Glen Mary is an old favorite still popular with many growers. Price list, page 35.

Haverland. A popular old standard. The fruit is of large size, rather light in color and firm enough to stand shipment in good shape. The blossoms are imperfect and exceedingly hardy, making it very desirable where late frosts are likely. Dunlap, Big Joe and Eaton are all good varieties to pollenize Haverland. The plants should be well mulched if possible, as the fruit stems are not able to hold the immense loads of berries off the ground. Haverland has been very popular in Ohio, Indiana, and also in the Western part of North Carolina. Many growers still like it and make big money growing Haverland. Others are discarding it in favor of Premier and Big Joe. We have one customer who told us that he regularly makes over $\$ 1000$ per acre growing Haverland. He says it will sell on his market at a premium over many other varieties. Haverland is grown mostly by experienced strawberry growers. We have a fine stock of plants for them, or any others who want to try it. Price list, page 35.

Paul Jones. Except, possibly, Premier, Paul Jones is the most productive berry we have. It is a very vigorous grower and makes a strong, healthy plant bed under almost all conditions. In any sections where great quantities of berries are

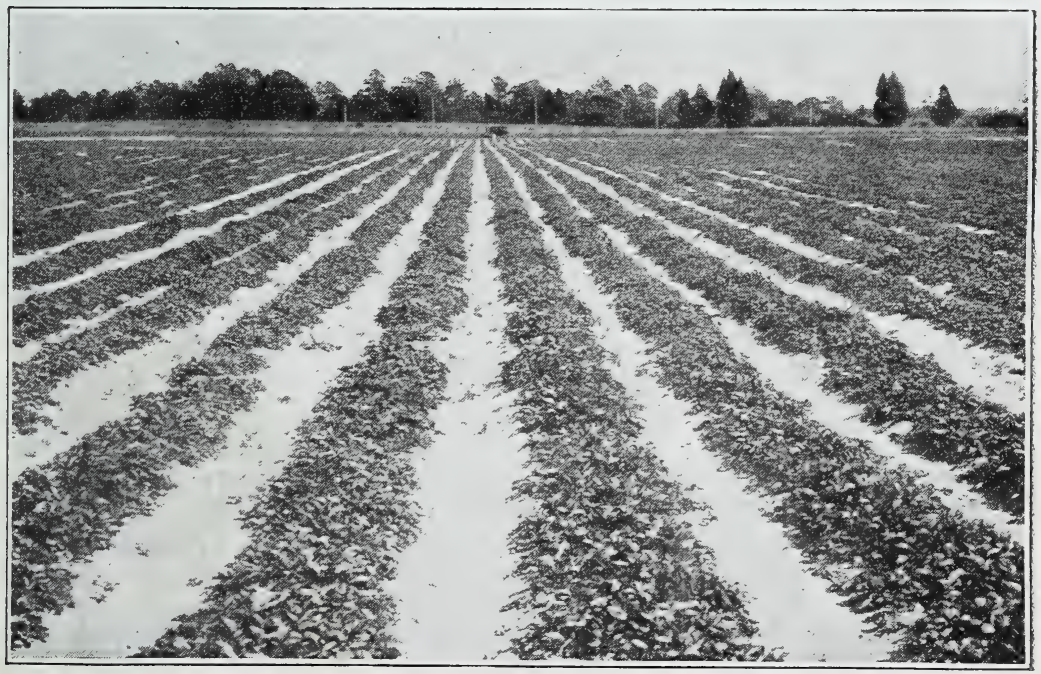

A fine field of Premier plants for our customers this spring 
wanted, Paul Jones should be quite valuable. It will produce tremendous crops of medium size, dark red berries, fairly good looking and fairly good in quality. It should be fruited with Big Joe, Senator Dunlap or McAlpin. The berries are rather long in shape somewhat resembling the Haverland, but are darker in color. We believe that, to get the greatest satisfaction and profits from your berry plantings, it would be better to plant the larger, fancier berries such as Premier for early, Big Joe or Eaton for mid-season, and Chesapeake, Big Late, McAlpin or Wm. Belt for late. We have a nice stock of Paul Jones plants and they sure do fill the boxes. Price list, page 35 .

JUST OUR WAY,

GLAD YOU LIKE IT

Wayne Co., Mich., May $5,1925$.

My strawberry plants arrived Saturday, May 2nd, and were planted in an

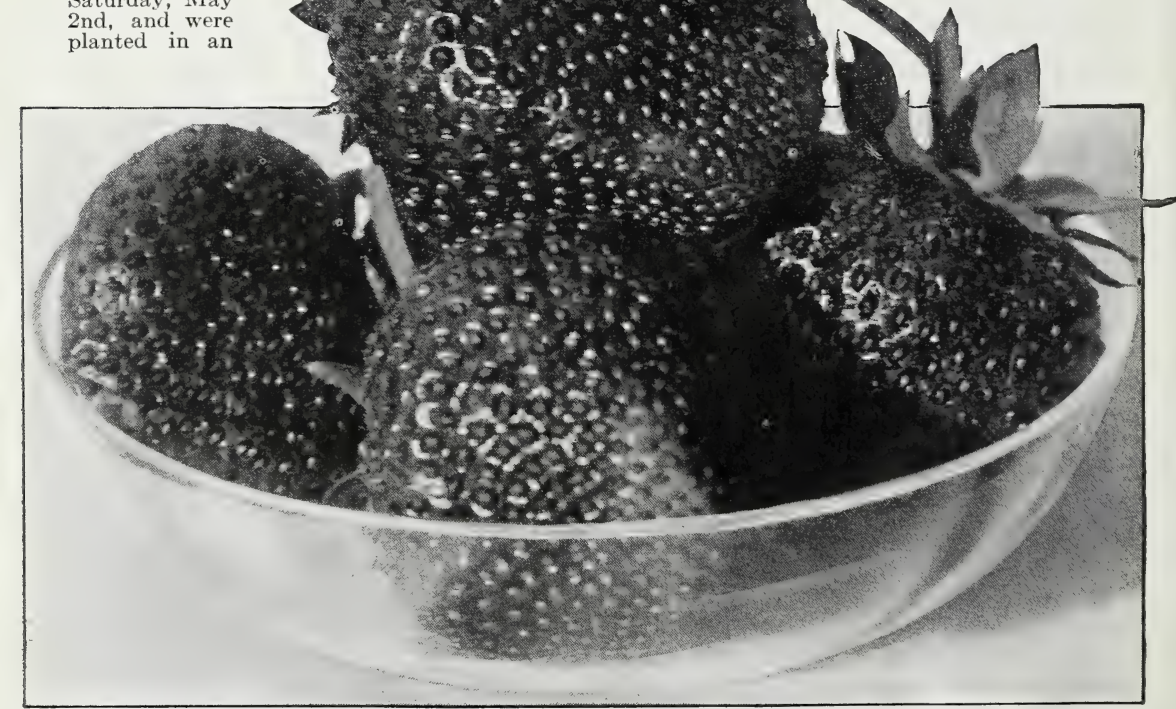

Chesapeake, the best late kerry.

\section{Chesapeake}

This is the best late berry ever introduced and is the only worthy running mate for Premier that we know of. We believe Chesapeake will outship and outsell any other strawberry ever put on the market. There are so many good points to Chesapeake that we are going to list them so as not to miss any.

1. The berries are large in size and hold up their size well to the end of the season. In this respect it is the best berry we ever saw, even beating Premier in this particular. We sold out our entire stock of plants last year, but in 1924 among about 40 of the leading varieties, our Chesapeake averaged larger in size than any other variety we had, even larger than Big Joe and lots larger than Cooper, much heralded as a fancy berry. 
2. The quality is of the very best. No other varieties except, possibly McAlpin, Wm. Belt and Big Late, equal Chesapeake in this respect. It is delicious.

3. The berries are firm enough to stand shipment to distant markets. In fact it will ship better than any other large berry we have ever grown. On our local auction markets solid carloads of Chesapeake will of ten bring $\$ 2.00$ or $\$ 3.00$ per crate of 32 quarts more than any other variety, except Gandy which sells with Chesapeake.

4. Due to the beautiful appearance, size, quality and firmness of the berries, they will outsell all other varieties.

5. Unlike Premier which will do well on all types of soil, rich or poor, Chesapeake needs land that has been well manured and it needs good care. Given these it will produce just enough strong, heavy rooted plants for a good fruiting bed. Chesapeake produces a medium number of large, strong plants rather than great quantities of small ones. It is hard to get great numbers of plants. That is the reason why many plant men do not push this variety, and the plants for the same reason can never be cheap as compared to Dunlap or Paul Jones, but the results are well worth paying a little more in order to get true-to-name Chesapeake.

6. Next to Premier Chesapeake has the healthiest foliage of any variety on our list. During the very wet picking season of 1924, Chesapeake and Premier were the only varieties we had that were almost entirely free from rust. They both produced a fine crop and were the only ones that did. Big Joe and Big Late ranked up well among all the other varieties in condition of the foliage and crop produced.

7. Almost frost proof. Premier withstands frosts on account of its very hardiness. Chesapeake, a late variety, almost always avoids frosts because it blooms very late, later than other varieties of the same season. Our attention was first called to this habit of late blossoming by the New York Agricultural Experiment Station, at Geneva, many years ago.

8. When canning or preserving, Chespeake will retain the shape and flavor as well or better than any berry we have ever tried.

9. The plants are very productive. They do not set enormous numbers of small berries but they do set plenty for a fine crop, and for this reason they can size them up better and hold the size throughout the season better than if large numbers of small berries were set which are never matured.

10. Chesapeake is a money-maker. As Mr. Albert Reynolds, of Chester County, Pa., said, "You don't have to pick so many to get a dollar." Chesapeake will sell for big prices when the demand is strong and it will sell for good prices when many other varieties will not sell at all. Mr. J. T. Rickett, of Montgomery County, Ky., wrote us, "I would like to say that the Premier and Chesapeake plants I ordered of you for last year's crop made a yield at the rate of considerably more than $\$ 1000$ per acre. They were as fine as any of your pictures show." Take good care of Chesapeake and they will reward you well. Price list, page 35.

\section{FRIEND}

Windham Co., Conn., Mar. 7, 1925.

I am an old friend because I always get good plants of you. I got you a new friend last year. Mr. Johnson. He is all Allen, too, now. He has good reasons. His plants look fine. You have received another order this year from him, so we always look for good plants from your house. Wishing you a much larger business, I am yours às long as I need good plants.

Byron H. Billington.

\section{GLAD YOU LIKED THEM}

Middlesex Co., Mass., April 20, 1925.

I received the strawberry plants and they arrived in fine condition, and I must say they are the best looking strawberry plants I ever bought.

Howard S. SPINNEY 


\section{Late Varieties}

Aroma. The leading fancy market berry in many sections. Aroma is a vigorous grower and very produrtive. The berries are medium to large in size, rich in color, and of good quality. They have a perfect strawberry shape, the uniformity in shape and color being one of the reasons why they are so attractive. A handsome, bright green cap increases the beauty and selling price of the berries which are very firm and will carry to market in excellent condition. Blossoms are perfect. In many sections where large quantities of berries are shipped, Aroma is the only variety grown. It is a good one to plant with Sample and other imperfect flowering varieties of its season. Aroma has made many a dollar for those who grow it, and will no doubt make many more. Price list, page 35.

Big Late. This is one of the very best varieties on the market today. In vigor of plant growth it ranks high, making strong, healthy foliage which is rather light in color, somewhat resembling the Premier. In productiveness it also ranks at the very top with Premier and Paul Jones. In quality, only the very best varieties like Chesapeake, Wm. Belt and McAlpin, are equal to it. The long, heavy roots which the plants have, make Big Late very valuable in a dry season. In a wet year, the foliage resists rusting better than most varieties, equaling Big Joe in this respect, and surpassed only by Premier and Chesapeake. The berries average large in size and have a bright, glossy surface with prominent seeds somewhat resembling Chesapeake. Every berry is perfect in shape. This, with a bright, red, glossy surface and the attractive green cap, makes Big Late one of the most handsome berries that we grow. It is a good shipper and either for home market or distant market, it is one of the best varieties to plant. Growers who find Chesapeake hard to bed up, will not go wrong if they use Big Late for their main late berry. The blossoms are imperfect and should be fruited with some good variety like Big Joe, McAlpin, or Aroma. All these are fine varieties and mate up well with the Big Late. Price list, page 35.

Burgess. This variety was originated by Mr. Scott in Alabama. It is clamed to be a seedling of Aroma and to be much better than that fine old variety in every particular. Mr. Scott published the testimony of many leading citizens and berry growers in his section, stating what a fine variety Burgess was, as growing on Mr. Scott's place. We had few plants to fruit last spring and it looked very promising. We did not have enough to get a very definite idea about it, as we had very few plants, and they were on very high land. The season was dry and that combination is very hard on a late berry. We will say that if Burgess will beat Aroma as much in other respects as it does in vigor of plant growth, it will become a widely planted variety. We have a nice stock of plants and we believe it will pay those who are interested in late shipping berries to give Burgess a trial. Frice list, page 35 .

Gibson (Parson's Beauty). A vigorous grower which makes plenty of strong, healthy plants for a good fruiting bed. The plants are very productive and bear through a long season. They grow well on all types of soil. The berries are large, a beautiful dark red in color. The quality is fine, and this with a deep red color makes them very popular for canning. Not a shipping berry, but for home garden or local market, it is very valuable in many sections. It is suid in some places that you can grow two acres of Gibson and be independent, but we think that is rather overstating the matter. Price list, page 35.

Lupton. A large, very handsome berry and an excellent shipper. The berries average about as large as Chesapeake, almost as good a shipper, very attractive in appearance but only fair in quality. As quality is not especially important in a shipping berry, we at first thought Lupton might take the place of Chesapeake on soils that were not well manured and where they had difficulty in getting a good 
bed of Chesapeake. After several years trial we have concluded that it is no easier to grow Lupton than Chesapeake, and that while Lupton is a good variety, it is not as good as Chesapeake. For one thing, the foliage is nowhere near as healthy in a wet year. We have some nice plants for those who want to try them. Price list page 35 .

McAlpin. A very vigorous grower that will do well on light poor land, but also responds wonderfully to richer land and greater fertility. Will grow anywhere. The berries are medium to large in size, brilliant scarlet in color and unexcelled in quality. After a heavy rain during picking time the McAlpin will have less sand and dirt on the berries than any variety we know. This is important, especially where mulching materials are scarce and high priced. Its excellent quality makes McAlpin a good one for the home or local market. It is also an excellent shipper, bringing top market prices. Beautiful in appearance, very productive and unsurpassed in quality. McAlpin planted with Big Late, makes a dandy combination and one that has made money for us the last few years. For vigor, quality, productiveness and all-round merit, McAlpin is hard to beat. The one weak point of McAlpin is that the foliage rusts considerably during a wet season. McAlpin grows so vigorously and makes so many plants that it is necessary to keep them thinned somewhat or they will get so thick that they cannot produce the best crop of fruit. Price list, page 35.

New York. This is the sweetest strawberry grown. The plant is a vigorous grower. The foliage is very healthy and the plants are quite productive. The berries are medium to large in size, dark red in color, and as stated above, the sweetest strawberry grown. It is the only strawberry we know that is sweet before it gets ripe. It is a favorite with many for the home garden. We have many calls for

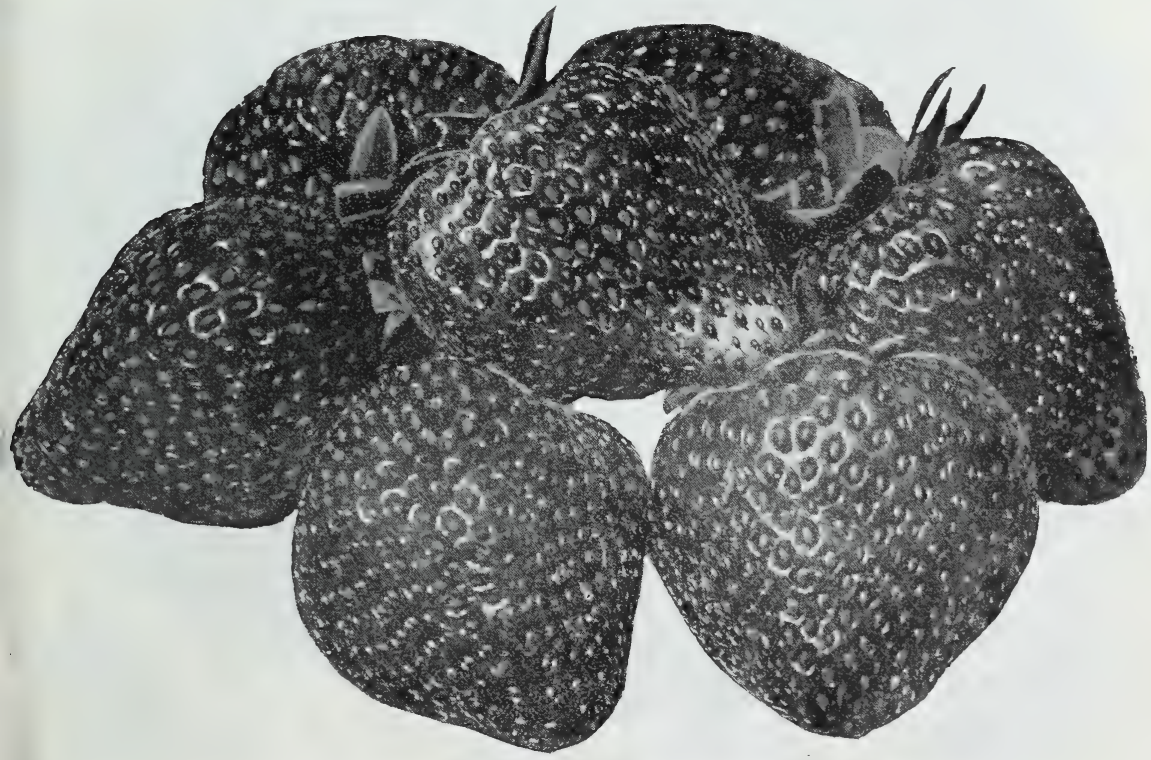

Big Late-Leads in çuality, beauty and productiveness 
New York from those whose health does not permit them to eat berries which are in any way tart or acid in quality. Price, $60 \mathrm{c}$ for 25 plants, 90 c for 50 plants, $\$ 1.50$ for 100 plants.

Parson's Beauty (Gibson). Same description as for Gibson. The varieties are identical, being grown in some sections under one name and in others under the other name. They produce large quantities of high quality berries which are deep red in color and part easily from the cap, making them very fine for canning and preserving. Price list, page 35 .

Sample. This is another old variety which has stood the test of time and still ranked hy many as the hest l te strawberry grown. The berries are uniform,

\section{PLANTS, SERVICE AND PRICES SATISFACTORY}

New London Co., Conn., Mar. 28, 1925.

My order 2749 has arrived. Your plants, service and prices are satisfactory to me. JAMES S. CASE.

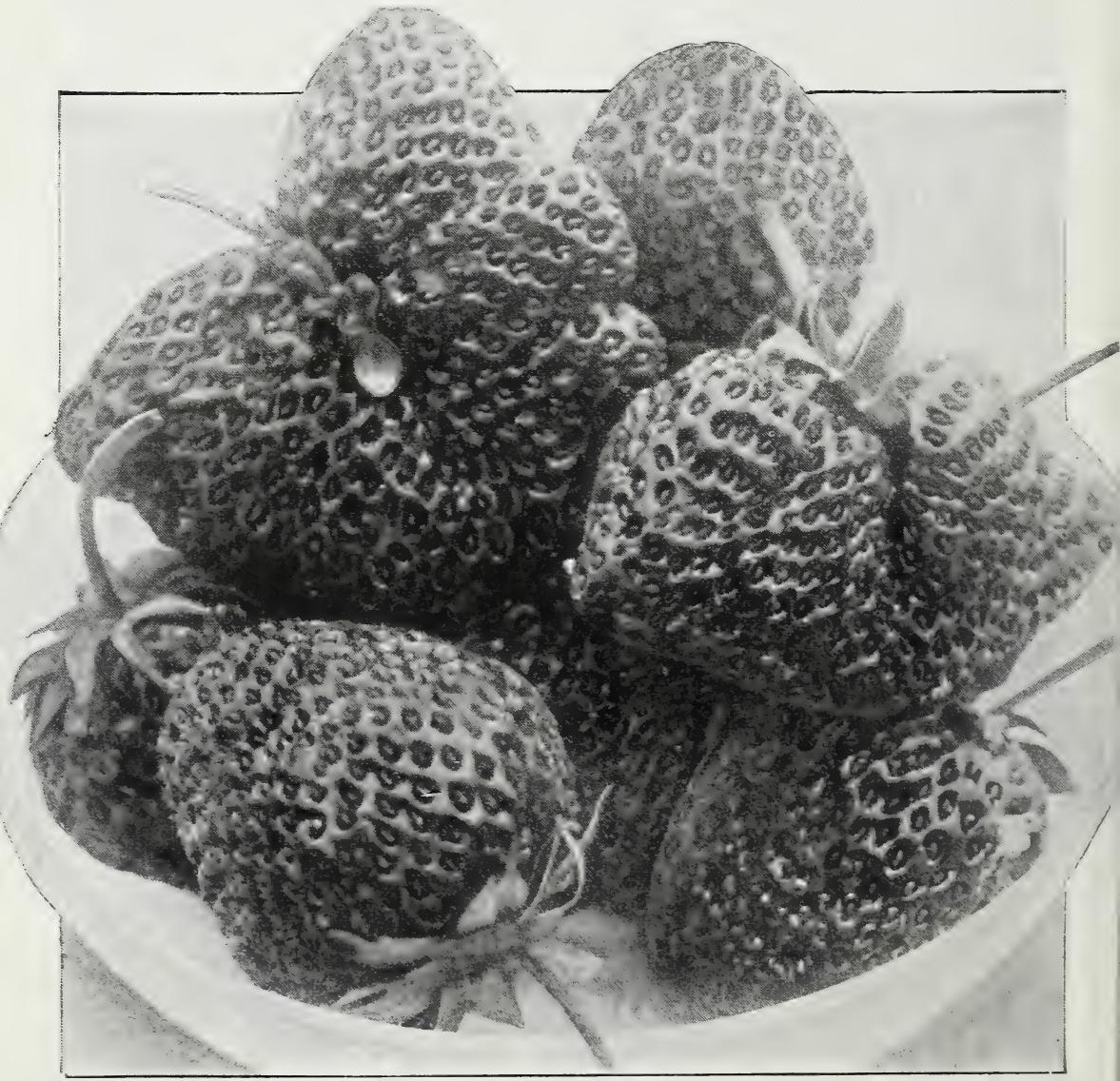

Wm. Belt, unsurpassed in quality 
bright red in color, large in size, very fine in flavor and attractive in appearance. They are not real firm but for local or nearby market, Sample has proven a moneymaker for many growers. It is enormously productive and does well on a wide range of soils. It seems to be most popular in the Middle and Northern States. It is very hardy and nearly always produces a crop. The blossoms are imperfect and should be planted with Big Joe, Eaton, McAlpin, or Aroma. Many growers still get fine results from Sample and will continue to grow it. We have a fine stock of plants for them. We would prefer Eaton or Big Late, but, realizing as we do how much different climate and soil can influence varieties, we can readily see why many still continue growing Sample. Price list, page 35.

Wm. Belt. On most markets the size and appearance of strawberries determine the selling price, but where quality is counted in addition to large size and handsome appearance, Wm. Belt should be grown. This variety is the standard of excellence for quality. The berries average large in size, somewhat irregular in shape as shown in the picture, but they have an attractive cap and the berries themselves are a bright glossy red which makes them very handsome. This variety does best in the middle and Northern States, and whether used in the garden, for local market, or nearby shipping, Wm. Belt is a friend to the strawberry grower and on account of its quality an even better friend to the strawberry consumer. Many growers are using Wm. Belt to extend the season after Chesapeake, or to take its place where they have tried Chesapeake and found the land not suited to that variety. Price list page 35.

\section{Very Late Varieties}

Gandy. This variety for years has ranked as a leader among the fancy late shipping berries. If Gandy were only a little more productive, it would continue to hold a place at the very top. Gandy likes black, swampy land or springy land that is not too sandy. We believe Gandy is the only late-shipping berry that equals Chesapeake in size, attractiveness and shipping qualities. It usually sells about with Chesapeake, but is not as good in quality and not as productive. This would be more important on a local or nearby market. Gandy is a good grower and it is no trouble to get a good fruiting bed. Price list, page 35.

Orem. This is the latest berry we have. The berries average large in size, are of good quality and handsome in appearance. They sell well because they come after all other fancy late berries are past their prime. Many growers want Orem because it is so very late, but we feel that Wm. Belt is easier to grow, produces berries equally large and better in quality. It lasts almost as long, but not quite, as the Orem. Our stock of plants of this variety is fine in quality but limited in quantity. Price list, page 35 .

\section{Everbearing Strawberries}

The last berry of the season, the last peach, or the last of any fruit always tastes the best. Usually it is necessary to wait a whole year before the season for that fruit comes again. This was true of the delicious strawberry until the advent of the Everbearing varieties. Now, however, it is no longer necessary to wait a whole year for more berries. They can be had in your own garden from mid-summer to freezing weather, long after the regular berry season is over. And it is not necessary to sacrifice quality either because the Everbearing berries are just as good as the spring berries. For the home garden the Everbearing strawberry is indispensable.

\section{PROMPTNESS APPRECIATED}

New Castle Co., Del., Apr. 14, 1925.

Enclosed please find my check of $\$ 7.93$ payment for strawberry plants I received in good condition, and plants are fine. Thank you for your promptness. With best wishes,

Joseph H. Grandhomme. 
As a money making proposition we do not recommend Everbearing strawberries indiscriminately. Many of our customers report to us that they make big money from Everbearing strawberries, but we believe that in order to do this conditions must be just right. A good rich plot of ground and a local market that will take the fruit at from $25 \mathrm{c}$ to $40 \mathrm{c}$ per quart without the expense of shipping very far is necessary.

Under good conditions one everbearing plant set in spring should produce about one quart of berries during the summer and early fall. They are grown just as other strawberries, except that after planting in early spring the blossoms should be kept cut off until about the first of July. Soon after they will commence bearing and continue until freezing weather.

Many varieties of Everbearing strawberries have been tested in our fields. Among those we have tested are Superb, Americus, Peerless, Rockhill, Perfection, Ideal, Lucky Boy and others. They are all so far inferior to Progressive and Champion that there is no reason for growing them. We are following a policy of offering only the best varieties in cutting our list of Everbearers down to Progressive and Champion with one new variety, Mastodon.

\section{PROGRESSIVE}

Progressive is the variety that really put the Everbearers on the map. It does well as a home garden proposition in all sections. It is the only Everbearer we have found that does well in the South. The berries are medium in size, not quite as large as we used to get from Superb and Peerless but it is vastly more productive and the berries are simply delicious in quality. If kept picked up close, the berries are firm enough to stand shipment short distances. Keep in mind that with the Everbearers you commence picking your crop of berries only a few weeks after the plants are set. If you and your family like strawberries, include some Progressive for your garden with the order this year. Perhaps it has done well enough so that you want to try a larger plot for market. If so, we will be glad to supply you some fine plants to start with. Price-list page 35.

\section{CHAMPION}

After growing Champion for several years we still find it to be practically the same as Progressive. The berries are identical in size, shape, appearance and quality. The plant growth of one cannot be distinguished from the other. It is claimed by the introducer and many other berry and plant growers that Champion bears more berries than the Progressive. Over a period of four or five years, we have seen very little difference in this respect. This year our plants of Champion have made a somewhat better growth than Progressive, but we have had Progressive just as good in plant growth as our Champion are this season. At any rate, Champion and Progressive are the very best of all the Everbearing sorts, and you will not go far wrong in planting either of them in your garden. Our stock of Champion was obtained directly from the introducer so we have it pure. Price list, page 35.

Mastodon. This variety is very highly recommended expecially by Michigan plant growers. It originated in Northern Indiana several years ago. Some of the important features claimed for it are its unusual size, being much larger than any other Everbearer and holding its size until the end of the season. It is claimed to be much sweeter than other Everbearers and also of a firmer texture, so that it is able to stand distant shipments. It is also said to be an unusual plant maker, making more plants than other everbearing varieties and as many as the average 


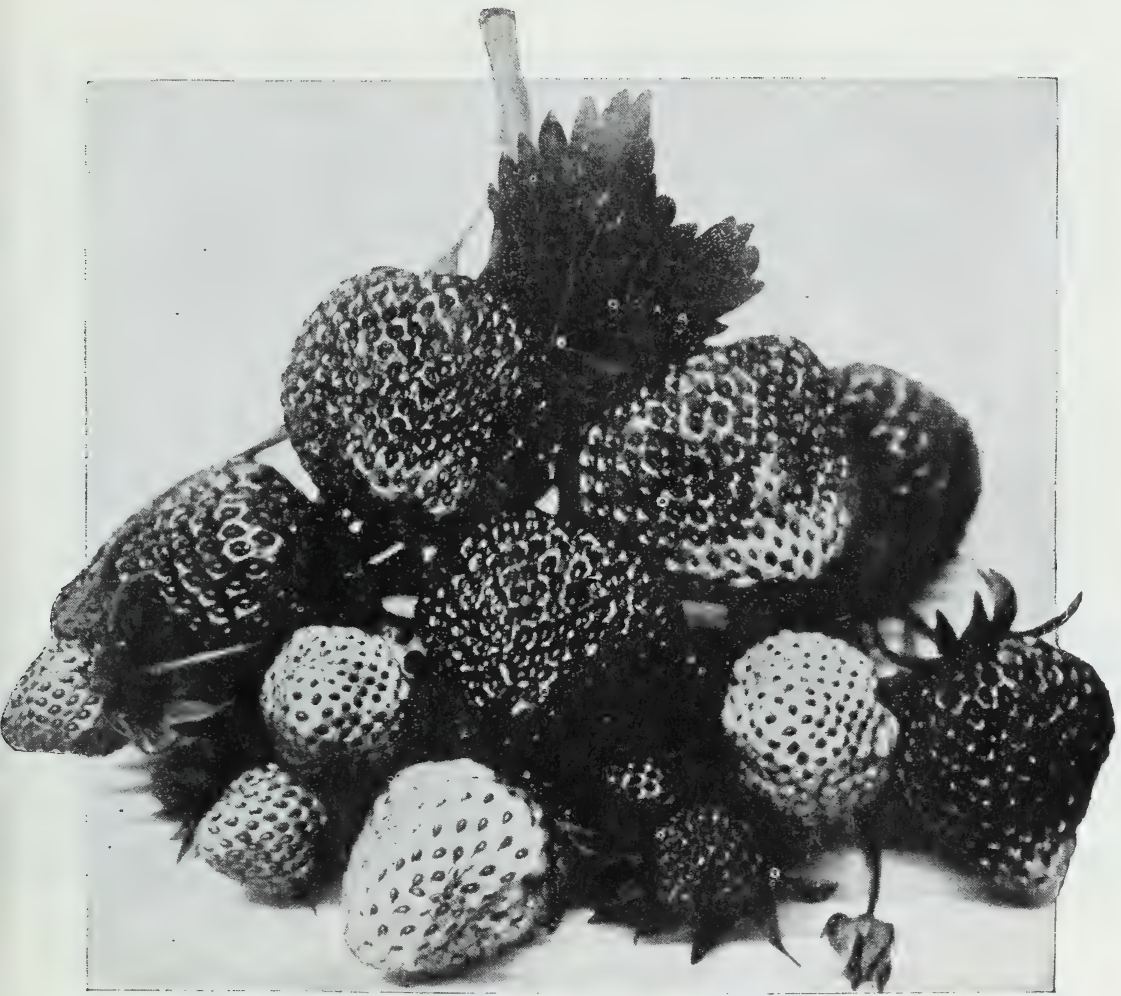

The Real Champion of the Everbearers

spring fruiting variety. One grower says that Mastodon is as far ahead of Champion as Champion is ahead of the many poorer Everbearers which have been on the market during the last few years.

All the above is taken from descriptions of the variety by Michigan growers. With us, Mastodon has made a fairly good plant growth, somewhat better than Progressive and Champion usually make, but not as good as our Champion have made this year. The season here was very dry, making it hard for an Everbearing variety especially to be at its best. However, it produced a fair amount of good, big berries which were very attractive in appearance and fairly good in quality. It produced more than Superb, Peerless, Perfection and berries of that type have produced for us.

But as compared with Champion, this season Champion has produced twice as many quarts of berries as the Mastodon, per plant, and they are, in our opinion, considerably better in quality than Mastodon. Perhaps another year that is not quite so dry, the Mastodon may show up better as compared with Champion. At present we consider it the most promising of that type of Everbearers which produce a moderate quantity of large berries rather than a heavy crop of medium sized berries. We have only a small stock and the price is as follows: 25 plants, $\$ 2.00 ; 50$ plants, $\$ 3.50 ; 100$ plants, $\$ 5.00$. 


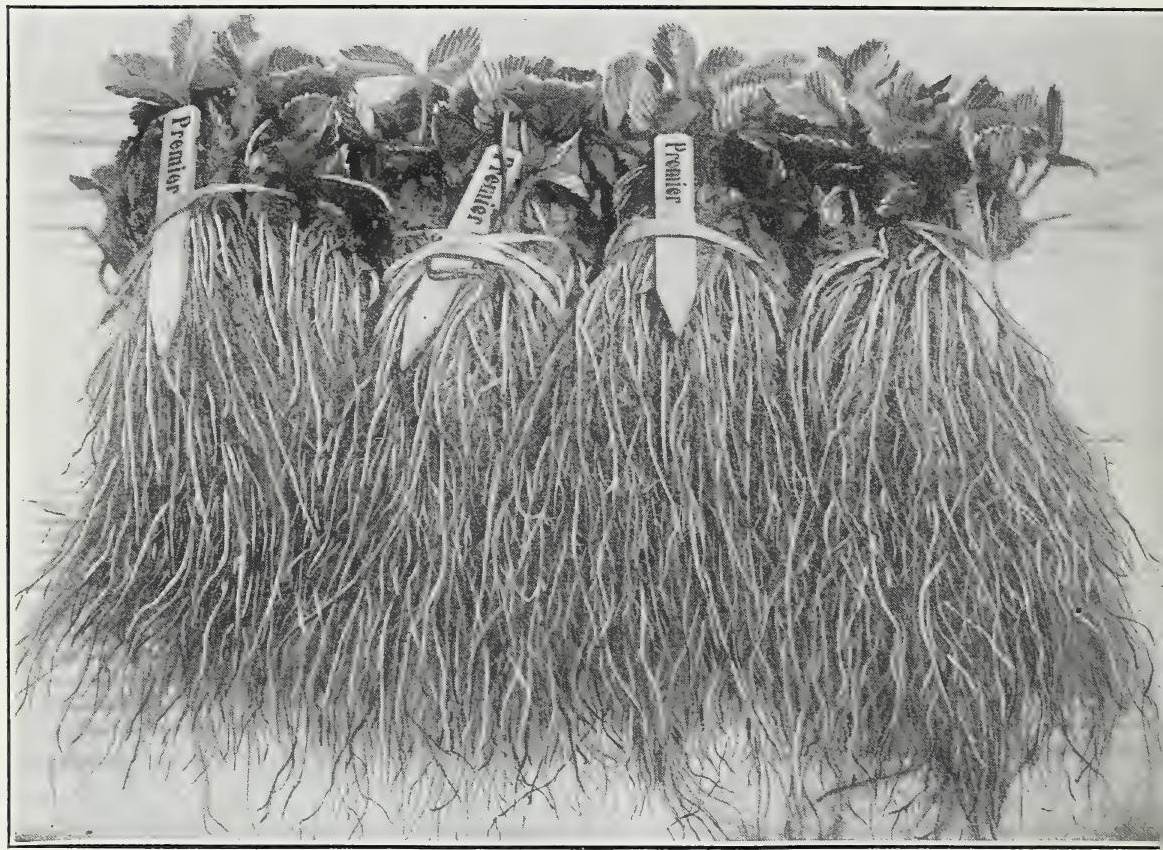

Good Plants produce Good Crops

\section{Reap All the Benefits}

In the Middle and Northern States the earlier your plants are set in spring, the better your chances of success. Just as soon as weather permits your ground should be prepared and the plants set. A difference of a few days in setting will often make more difference in resulting growth and crop than a heavy coating of manure or fertilizer. This is not theory. It has happened with us, and with many others. In a season of low prices this might make the difference between profit and loss. If high prices, the loss by late planting will be all the greater.

Northern Grown Plants, if properly grown and handled, may be good plants. But if you depend on plants from Northern States, you stand a chance of losing all or a part of the advantage of early planting. Your plants should be on hand to set just as soon as the ground is ready. Your northern plants may or may not be dug by that time, depending on weather conditions. Delays in transportation may hold up early planting. We are fortunately situated to take care of you in this respect. We have hard winters, but our springs open up in time to dig plants and have them delivered to you in time to reap all the benefits of Early Planting.

\section{A FINE COMPLIMENT}

Lancaster Co., Pa., April 13, 1925.

Received my strawberry plants on Wednesday, 8th, and must say they were the finest plants I ever received from any nurseryman, as I have received a great many plants from other firms. Also thank you for returning the extra postage.

Thanking you for past favors, and wishing you future success, I am

C. B. MrLiN 


\section{Instructions to Purchasers}

Order At Once, as soon as convenient after receiving this catalog. Late in the season we may be sold out of some varieties, but if ordered early the plants are reserved for you, to be shipped at proper time for planting. This is especially important this year when high prices for berries have made such a big demand for plants. Reporis we have from growers all over the country indicate that the crop is very short. To be doubly sure of getting just what you want when you want it, ORDER EARLY. Read "Time to Plant-Important," page 9.

Remit by Money Order, Registered Letter, or Bank Draft, Postage Stamps will be accepted for the fractional parts of a dollar, the larger denominations preferred. Foreign customers will please send Money Orders on Salisbury, Maryland, or Bank Draft payable in New York.

Write Plainly. Fill in all blanks on the sheet, as they are necessary for proper shipment, especially your name and address. When writing in reference to an order, give its number and give your name the same as was sent on the order.

Time of Shipment. We commence to fill fall orders Nov. 1st, and ship all winter to sections where the conditions are suitable for fall and winter plantings, as in California and some parts of the South. Early, Spring, March and April, is by far the best time to set strawberry plants in the middle and northern states. Our shipping season ends May 1st. We will, however, fill a limited number of orders in the first and second week of May and put them in the best possible condition, but at purchaser's risk. It is very important to have your plants shipped early. Read on page 9 under "Time to Plant." The reason your plants should be shipped early in the season is that plants are dormant and will stand digging and shipping much better than after the growth has started. Don't order plants from us during the summer months, excepting orders to be filled before the first of November. Our plants are not ready and we can't do it. We don't grow potted plants.

On Receipt of Plants. Where the climate is not so severe, place the package containing the plants in a cool place, protected from wind and sun, at once on arrival. Be sure to keep the roots moistened while planting. If it is impossible to set the plants as soon as received take them out of the crates, and bed them in by digging a V-shaped trench in soft moist soil, preferably in the shade; open the bunches of plants and bed them in the trench by pressing the soil firmly to the roots, being careful not to cover the buds or crowns. Water thoroughly as soon as bedded.

Twenty-five. All plants are tied twenty-five in a bundle and each bundle labeled.

Packing. We make no charges for boxing or packing at rates quoted in this catalog. Everything is delivered f. o. b. trains at rates named.

At Purchaser's Risk. All plants ordered shipped after May 1st will be packed and shipped in the best condition possible, but at purchaser's risk.

True-to-Name. While we use every precaution to have all plants true-toname (and we believe we come as near doing this as anyone in the business) we will not be responsible for any sum greater than the cost of the stock, should any prove otherwise than as represented.

CLAIMS, if any, must be made on receipt of plants. Call for your plants as soon as they arrive. Protect plants from sun and wind until planted. We pack plants to reach you in good condition. We cannot be responsible for drought, floods, insects, after planting. These things are entirely beyond our control.

Should there be a shortage in your order, report at once number of packages and number of plants of each variety received. This will enable us to promptly adjust any discrepancy. Often the transportation company will separate a shipment and the balance of your plants will come in on the next train. 


\section{Prices}

Our prices are high enough to allow us to do all that can be done to grow good, strong, thrifty, well-rooted plants, keep them true-to-name, dig and prepare them properly for shipment and allow us a reasonable profit. "Bargains" may be alright for shoes, hats, etc., where only the actual money spent is risked, but the time, effort, and money required to grow a profitable strawberry garden should not be wasted or risked with "bargain" plants of poor or uncertain quality.

Our plants are priced about the same as last year. They are $\$ 1.00$ or more per 1000 less on several varieties and $\$ 1.00$ per 1000 more on two or three varieties.

Our prices are reasonable for the quality of plants we send out. They are not high. They are fair. A fair price for good plants is a sound investment. You buy insurance against fire or life. Allen's good true-to-name plants are your insurance against a poor start in your strawberry garden.

\section{WHY ORDER EARLY?}

1. Early planting pays big. Look over the Berry Book and decide on what you want and place the order while you have the time-before the rush of spring work starts in. If you wait until your ground is prepared before ordering, you will miss the best planting time.

2. Early ordering gives us a better chance to handle your order in time. The clerical work is completed and we know in advance what to prepare to dig on certain dates to get orders out promptly.

3. If your order is placed early, we reserve the varieties you want to plant. If you delay, you may not get what you had rather have. We send out many thousands of these berry books and have many thousands of customers whom we are glad to count as friends. Lots of them, good farmers and gardeners, appreciate our "Good plants and true-to-name," and place their orders so that what they want will be reserved for them. We have a fine large stock of plants but we sell a lot of plants. For example, not over two years in the last ten have we had enough Chesapeake to supply all our calls for this variety. First come, first served.

\section{HOW TO SHIP}

Express is generally satisfactory and the best way to ship plants if your order is large or if the distance is great.

Parcel Post. Generally cheapest and most satisfactory for small shipments and with larger shipments in adjoining and near-by states.

Strawberry plants packed for shipment weigh approximately 4 pounds per 100 plants. Make up your order, calculate the approximate weight and if you do not know your zone from Salisbury, Maryland, use distances given below, or ask your postmaster.

With the zone rate published below, you can easily calculate the amount of postage to send. Be sure to send postage enough. If you should send more than is required, the excess will be returned. If sufficient amount to pay parcel post charges are not sent with the order the plants will be sent by Express collect, or by parcel post, c. o. d. for the amount of postage due, as we cannot keep accounts and send bills for small items of postage.

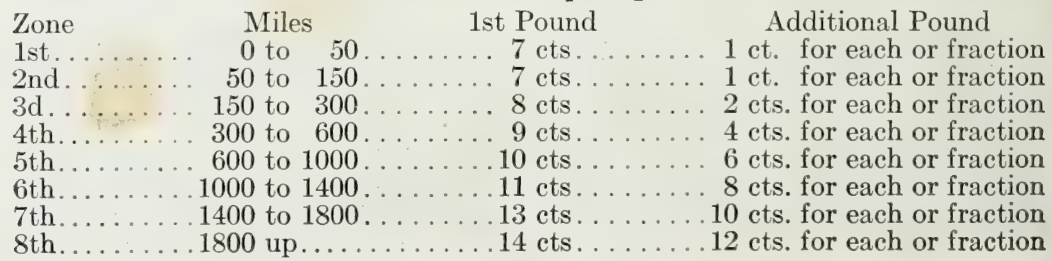




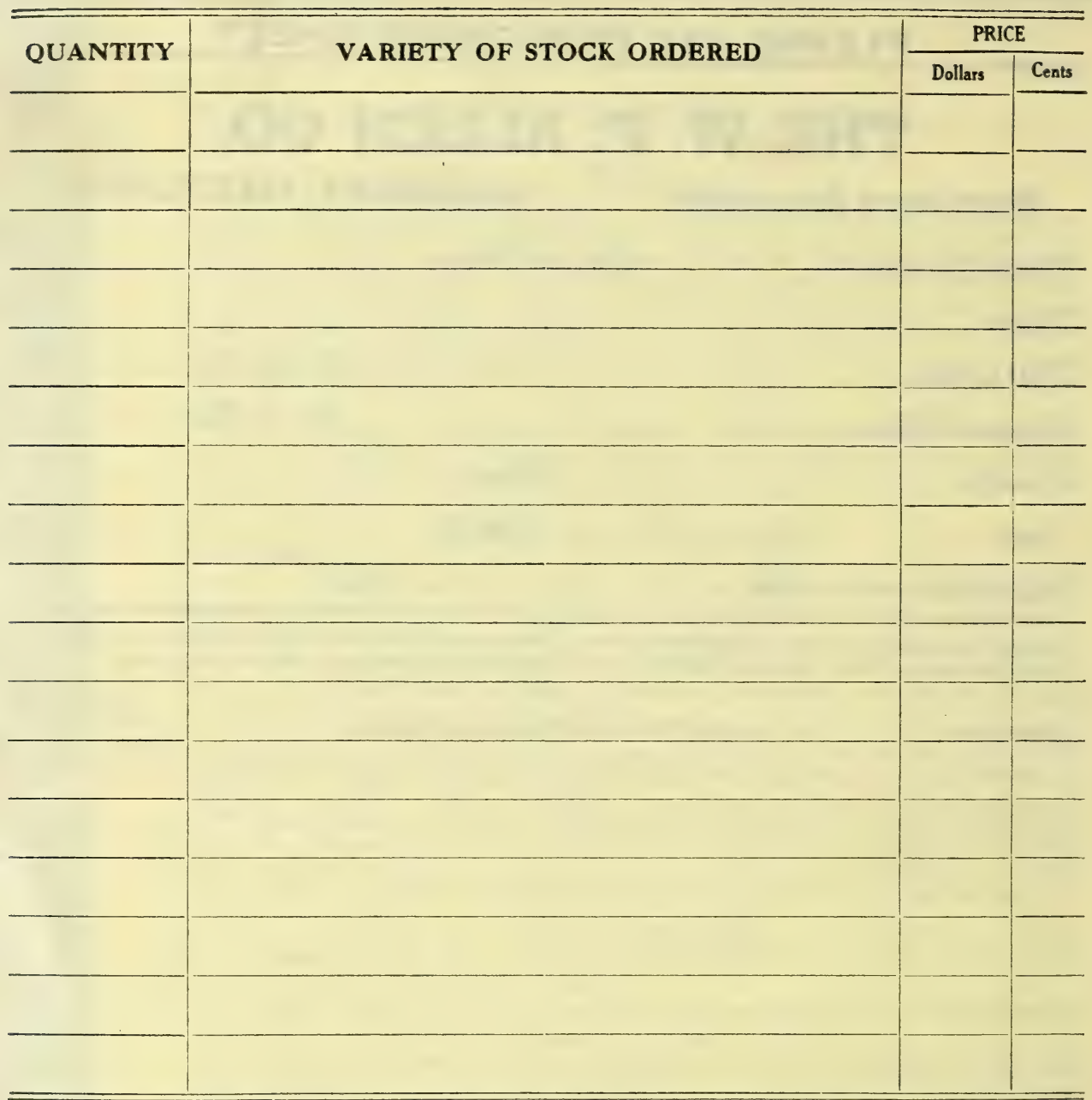

TRUE TO NAME. While we use every precaution to have all plants, etc., true to name (we believe we come as near doing this as anyone in the business), we will not be responsible for any sum greater than the cost of the stock should any prove otherwise than as represented.

Please write below the names and addresses of any acquaintances or friends who might be interested in, or buyers of, strawberry or other small-fruit plants 


\section{Price List of Strawberry Plants}

Description

Page

Extra Early Varieties

18 Premier (Per) ....... \$6.00

19 Howard 17 (Per) . . . . 6.00

\section{Medium Early Varieties}

20 Cooper (Per)

7.00

21 Dr. Burrill (Per) . . . . . 5.00

21 Sussex (Per).

21 Klondyke (Per) . . . . . 4.00

22 Missionary (Per) ...... 4.00

20 Senator Dunlap (Per). . 5.00

\section{Midseason Varieties}

22 Big Joe (Per) . . . . . . . 6.00

22 Eaton (Per) .......... 7.00

23 Glen Mary (Per) ... . . . 8.00

23 Haverland (Imp.) . . . . 7.00

23 Paul Jones (Imp.) . . . . 6.00
Description

Page

Price

Per 1,000

\section{Late Varieties}

26 Aroma (Per) ..... . . \$ \$6.00

26 Big Late (Imp.) . . . . . . 7.00

26 Burgess (Per) ........ . 8.00

24 Chesapeake (Per) . . . . 8.00

26 Gibson (Per) . . . . . . . 6.00

26 Lupton (Per) . . . . . . 7.00

27 McAlpin (Per)...... 6.00

27 New York (Per) See Page 27

28 Parsons Beauty (Per) . . 6.00

28 Sample (Imp.) . . . . . . 6.00

28 Wm. Belt (Per) . . . . . 7.00

Very Late Varieties

28 Gandy (Per) . . . . . . . 6.00

28 Orem (Per) . . . . . . . . 8.00

\section{Everbearing Varieties}

30 Champion (Per) ..... 8.00

30 Progressive (Per) .... 8.00

30 Mastodon (Per) See

Page 30

\section{If Less Than 500 Plants of a Variety Are Ordered, Prices Must}

Be Carried Out According to the Following Table. If the Correct Amount Is Not Sent, We Will

Send Only the Quantity of Plants

You Have Paid For.

If priced at

25 plants will cost

50 plants will cost

75 plants will cost

100 plants will cost

150 plants will cost

200 plants will cost

250 plants will cost

300 plants will cost

350 plants will cost

400 plants will cost

450 plants will cost

500 plants will cost

1,000 plants will cost

\begin{tabular}{|c|c|c|c|c|}
\hline $\begin{array}{c}\$ 4.00 \\
\text { per }\end{array}$ & $\begin{array}{c}\$ 5.00 \\
\text { per }\end{array}$ & $\begin{array}{c}\$ 6.00 \\
\text { per }\end{array}$ & $\begin{array}{c}\$ 7.00 \\
\text { per }\end{array}$ & $\begin{array}{c}\$ 8.00 \\
\text { per }\end{array}$ \\
\hline 1,000 & 1,000 & 1,000 & 1,000 & 1,000 \\
\hline .25 & .30 & .40 & .50 & .50 \\
\hline .40 & .50 & .60 & .70 & .80 \\
\hline .55 & .70 & .80 & .90 & 1.05 \\
\hline .70 & .90 & 1.00 & 1.10 & 1.30 \\
\hline .90 & 1.15 & 1.30 & 1.45 & 1.65 \\
\hline 1.10 & 1.40 & 1.60 & 1.80 & 2.00 \\
\hline 1.25 & 1.60 & 1.90 & 2.15 & 2.35 \\
\hline 1.40 & 1.80 & 2.15 & 2.45 & 2.70 \\
\hline 1.55 & 2.00 & 2.30 & 2.75 & 3.05 \\
\hline 1.70 & 2.20 & 2.60 & 3.00 & 3.40 \\
\hline 1.85 & 2.35 & 2.80 & 3.25 & 3.70 \\
\hline 2.00 & 2.50 & 3.00 & 3.50 & 4.00 \\
\hline 4.00 & 5.00 & 6.00 & 7.00 & 8.00 \\
\hline
\end{tabular}




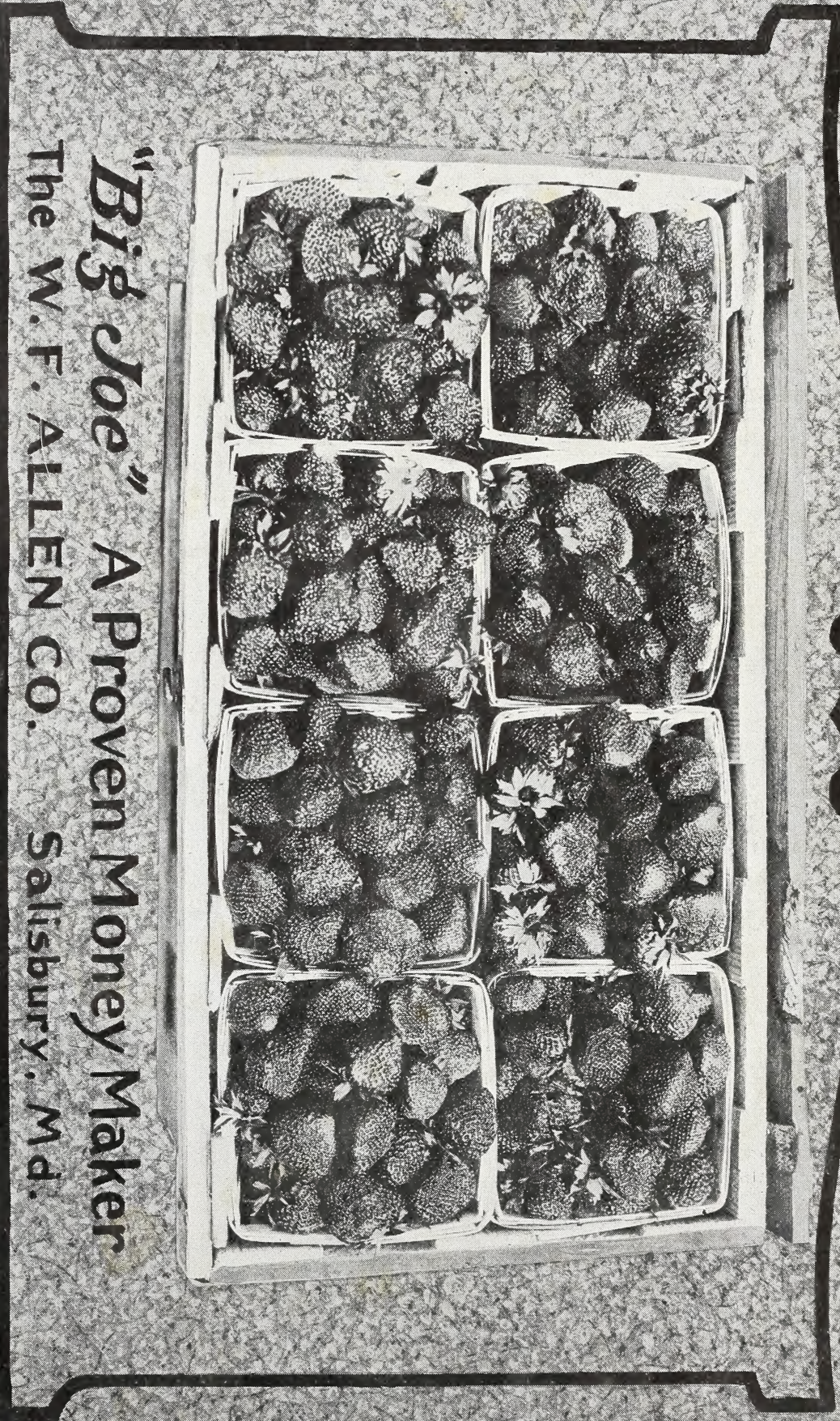



